ISSN 1045-6333

\title{
PROPERTY RIGHTS AND LIABILITY RULES: THE EX ANTE VIEW OF THE CATHEDRAL
}

\author{
Lucian Arye Bebchuk
}

Discussion Paper No. 347

$12 / 2001$

\author{
Harvard Law School \\ Cambridge, MA 02138
}

The Center for Law, Economics, and Business is supported by a grant from the John M. Olin Foundation.

This paper can be downloaded without charge from:

The Harvard John M. Olin Discussion Paper Series: http://www.law.harvard.edu/programs/olin center/ 


\title{
PROPERTY RIGHTS AND LIABILITY RULES: THE EX ANTE VIEW OF THE CATHEDRAL
}

\author{
Lucian Arye Bebchuk*
}

\begin{abstract}
$\underline{\text { Abstract }}$
Beginning with Calabresi's and Melamed's seminal article, economic analysis of property rights and liability rules has been largely done from an ex post perspective, taking as given the presence of the parties involved and their payoffs. This paper analyzes how such allocation of entitlements affects ex ante investments and actions. Even when ex post bargaining is easy, the ex post allocation of entitlements, by affecting the distribution of ex post value, can have significant efficiency effects ex ante. By identifying the ex ante effects of alternative rules, the analysis provides a framework for determining allocations of entitlement that would perform best from the perspective of ex ante efficiency.

Key words: externalities, property rights, liability rules, ex ante investments, regulation.

JEL classification: D62, K10, K11.

(C2001 Lucian Bebchuk. All rights reserved.
\end{abstract}

* William J. Friedman \& Alicia Townsend Friedman Professor of Law, Economics and Finance, Harvard Law School; Research Associate, National Bureau of Economic Research and Center for Economic Policy Research. A companion piece, "Ex Ante Investments and Ex Post externalities," available on SSRN, develops a formal model that establishes in a more general and rigorous way the claims made informally in this paper. I am indebted to Assaf Hamdani for his invaluable assistance. I also benefited from the helpful comments of Oren BarGill, Omri Ben-Shahar, Bob Ellickson, Bert Huang, Oliver Hart, Ryan Kantor, Louis Kaplow, Suzanne Scotchmer, Steve Shavell, and participants in workshops at Berkeley, Harvard, Hamburg, and Michigan. The financial support of the Harvard Law School John M. Olin Center for Law, Economics and Business is gratefully acknowledged. 
The Ex Ante View of the Cathedral

TABLE OF CONTENTS

I.INTRODUCtion: Alternative VIEWS OF THE CATHEDRAL .........................1

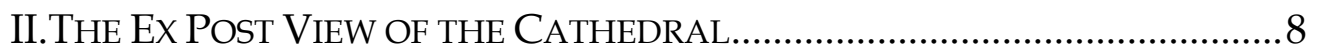

A. The Conflicting-Use Problem .......................................................

B. The Efficient Ex Post Outcome ………………............................10

C. Law's Choice: Calabresi and Melamed's Four Rules ....................12

D. Ex Post v. Ex Ante Efficiency ......................................................14

1. From Ex Post to Ex Ante ..........................................................14

2. Ex Post Distribution Does Matter for Efficiency .....................15

3. The Choice of Rule Matters Even When Ex Post Bargaining Is

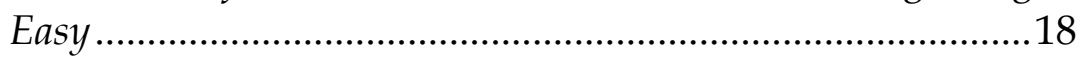

III.THe EFFeCt OF Rules ON THE EX Post Division of VALue...................19

A. Scenario FR: Factory and Resort Should Both Operate................20

B. Scenario F: Only Factory Should Operate ....................................22

C. Scenario R: Only Resort Should Operate ………………..............23

IV.THE Ex ANTE EFFECTS Of Alternative Rules........................................26

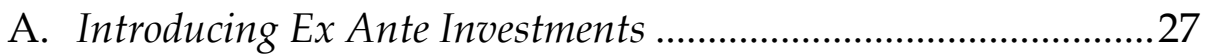

B. Investment by Factory to Enhance the Value of Its Activity........29

1. The Optimal Investment Level ...............................................29

2. Investment Under Alternative Rules .......................................29

C. Resort's Ex Ante Investment to Enhance the Value of Its Activity

.

1. The Optimal Investment Level ...................................................34

2. Investment Under Alternative Rules .........................................34

D. Ex Ante Investments in Harm Reduction .....................................39

1. Optimal Investment Levels ........................................................39

2. Investments Under Alternative Rules .......................................40

E. Taking Stock ................................................................................ 44

V.IMPLICATIONS FOR THE CHOICE OF RULE..................................................45

A. Property-Right Protection vs. Liability-Rule Protection ................46

B. Which Party Should Get the Entitlement? ...................................47

C. Should We Expand the Menu of Rules? ........................................... 49

D. Taxes and Fines: Coase vs. Pigou Reconsidered .........................50

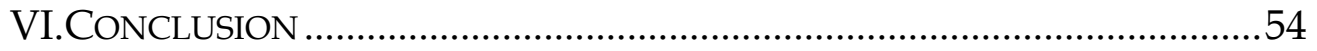




\section{INTRODUCTION: ALternAtive VIEWS OF THE CATHEDRAL}

This Paper aims to contribute to the study of how the law should allocate and protect entitlements in the presence of externalities. In their classic and influential article published thirty years ago, Calabresi and Melamed studied such questions and offered what they labeled "one view of the Cathedral."1 I seek to add to the inquiry started by Calabresi and Melamed by offering an ex ante perspective and analyzing how allocations of entitlements affect parties' ex ante actions and investments.

Suppose that an upstream Factory would benefit from an activity that pollutes a river and hurts an activity conducted by a downstream Resort. In this as in many other cases, the respective rights of the parties must be determined. Does Factory have the right to engage in the polluting activity, or does Resort have the right to water free of pollution? If Resort is entitled to unpolluted water, should it be protected by a property right or by a liability rule?2

1. Guido Calabresi \& A. Douglas Melamed, Property Rules, Liability Rules, and Inalienability: One View of the Cathedral, 85 HARV. L. REV. 1089 (1972). Scholars consider this article a part of the legal canon. See James E. Krier \& Stewart J. Schwab, The Cathedral at Twenty-Five: Citations and Impressions, 106 YALE L.J. 2121 (1997) (demonstrating the influence of the article through citation analysis); Carol M. Rose, The Shadow of The Cathedral, 106 YALE L.J. 2175 (1997) ("One View of the Cathedral is now so much a part of the legal canon that it is widely known by the joined names of its two authors....").

2. See Section II.C. infra. Calabresi and Melamed also examined an additional form of protection - inalienability rules. See Calabresi \& Melamed, supra note 1, at 1111-15. This paper, however, will focus, as much of the literature has done, on alienable rights that parties may sell or waive. For an economically oriented analysis of inalienability rules, see Susan Rose-Ackerman, Inalienability and the Theory of Property Rights, 85 COLUM. L. REV. 931 (1985). 


\section{The Ex Ante View of the Cathedral}

Calabresi and Melamed, and the subsequent extensive literature on the subject, 3 have primarily conducted what I will label an "ex post analysis." I use this phrase to refer to an analysis that takes as given the payoffs that parties would have with and without externalityproducing actions. In the above-considered example, an ex post analysis would take as fixed both the presence of Factory and Resort and their potential costs and benefits from their respective activities. Taking these elements of the situation as given, the analysis would examine which entitlement allocations would lead to the efficient level, if any, of pollution-producing activity on the part of Factory.

The common starting point for an ex post analysis is the Coasean insight that, in cases in which the relevant parties can relatively easily bargain ex post, the allocation of entitlements will matter little in terms of efficiency.4 As long as parties can bargain around legal rules, the ex post outcome will be always efficient. Given that bargaining is subject to transaction costs and imperfect information, however, such ex post efficiency cannot be guaranteed. The ex post analyses therefore examine which allocation of entitlements would most likely facilitate the efficient outcome in a world where such obstacles to bargaining exist.

This Paper focuses on how ex ante decisions are affected by allocations of entitlements. By ex ante decisions I mean throughout this Paper those decisions that (i) take place before decisions whether to

3. See, e.g., Ian Ayres \& J.M. Balkin, Legal Entitlements as Auctions: Property Rules, Liability Rules, and Beyond, 106 YALE L. J. 703 (1996); Ian Ayres \& Paul M. Goldbart, Optimal Delegation and Decoupling in the Design of Liability Rules, 100 MicH. L. REV. 1 (2001); Ian Ayres \& Eric Talley, Solomonic Bargaining: Dividing a Legal Entitlement to Facilitate Coasean Trade, 104 YALE L. J. 1027 (1995); Robert C. Ellickson, Alternatives to Zoning: Covenants, Nuisance Rules, and Fines as Land Use Controls, 40 U. CHI. L. REV. 681 (1973); Louis Kaplow \& Steven Shavell, Property Rules Versus Liability Rules: An Economic Analysis, 109 HARV. L. REV. 713 (1996); James E. Krier \& Stuart J. Schwab, Property Rules and Liability Rules: The Cathedral in Another Light, 70 N.Y.U. L. REV. 440 (1995); A. Mitchell Polinsky, Controlling Externalities and Protecting Entitlements: Property Right, Liability Rule, and TaxSubsidy Approaches, 8 J. LEGAL STUD. 1 (1979) [hereinafter Polinsky, Controlling Externalities]; A. Mitchell Polinsky, Resolving Nuisance Disputes: The Simple Economics of Injunctive and Damages Remedies, 32 STAN. L. REV. 1075 (1980) [hereinafter Polinsky, Resolving Nuisance Disputes].

4. R.H. Coase, The Problem of Social Cost, 3 J. LAW \& ECON. 1 (1960). 
Paper those decisions that (i) take place before decisions whether to undertake externality-producing actions are made, and (ii) influence the parties' potential payoffs with or without these externalityproducing actions. Thus, in the considered example, the ex post payoffs of Factory and Resort with and without pollution might be a product of the ex ante decisions by Factory and Resort whether to locate along the river in the first place and, if so, how close to the river to locate; what scope of activities to develop; what products or services to provide; how many workers to hire and how much to invest in their human capital; and so forth. Such ex ante decisions are ubiquitous, of course, and critically affect the ex post structure of cases the law must resolve. 5

To study the ex ante dimension of the Cathedral in isolation from the ex post problems extensively studied in prior work, I will put aside these problems by assuming that ex post bargaining between the parties is easy. I should stress, however, that I have no doubt that ex post considerations are important, and indeed essential, elements for legal decision-making in the externalities context. To highlight the important role that ex ante effects should play in an overall picture of the Cathedral, however, I will focus in this Paper on situations in which ex post bargaining is easy.

In examining the ex ante effects of alternative rules in such situations, my analysis builds on the large economic literature analyzing "incomplete contracts." 6 This literature has sought to analyze how the

5. Some of the researchers whose analysis focused on what I term ex post effects have also recognized the presence of what I term ex ante effects. In particular, Kaplow and Shavell, supra note 3, at 738-39, discuss how any protection of victims might discourage them from making investments that would reduce their potential harm from externality-producing actions. Kaplow and Shavell agree that such a factor might influence the choice of rule, but they do not attempt to reach conclusions as to the conditions under which, in the presence of such investments, any given rule would be optimal. Ayres and Talley, supra note 3, also discuss how ex ante considerations might militate against the use of liability rules, but they focus on the beneficial effect that liability rules have on ex post bargaining. Id. at 1083-90.

6. See generally, Oliver HART, FirMS, CONTRACTS, AND FINANCIAL STRUCTURE (1995) [hereinafter HART, FIRMS, CONTRACTS]; Sanford J. Grossman \& Oliver D. 


\section{The Ex Ante View of the Cathedral}

potential division of surplus in later renegotiations might affect earlier investments. Although this literature has focused on contractual contexts that differ from the harmful-externalities context on which I focus, its analytical approach has been useful for carrying out my analysis.

It is worthwhile highlighting at the outset some general differences between an ex ante and an ex post analysis. From an ex post perspective, the distribution of ex post value between the parties has no relevance for efficiency. To be sure, writers carrying on ex post analyses have differed on whether the distributive consequences of alternative rules have some importance by themselves, independent of goal of efficiency. Such writers have nevertheless generally shared the view that the ex post distribution is irrelevant from the perspective of efficiency itself. As the analysis of this Paper demonstrates, however, once ex ante effects are taken into account, the ex post division of value might have considerable efficiency implications. Different divisions of ex post value lead to different incentives for ex ante action and investment. As a result, a given rule's effects on the ex post division of the total pie have an important effect on the overall ex ante efficiency of the rule.

Relatedly, the introduction of ex ante effects also makes the choice of rule important in cases in which ex post bargaining is easy. The standard ex post analysis assumes that, when the parties can easily bargain ex post, the choice of legal rule has little or no relevance for efficiency. In such cases, ex post bargaining can be expected to produce an efficient outcome regardless of the initial allocation of entitlements. Therefore, prior work has focused on cases in which ex post bargaining is difficult or even impossible. As the analysis of this Paper will show, however, once we take ex ante effects into account, the choice of rule might have important efficiency implications even when ex post bargaining is easy. By affecting the bargaining positions of each party in the ex post bargaining, the choice of rule will affect the ex post divi-

Hart, The Costs and Benefits of Ownership: A Theory of Vertical and Lateral Integration, 94 J. POL. ECON., 691 (1986); Oliver Hart \& John Moore, Incomplete Contracts and Renegotiation, 56 ECONOMETRICA 755 (1988); Oliver Hart \& John Moore, Property Rights and the Nature of the Firm, 98 J. POL. ECON. 1119 (1990). 
sion of value. This ex post division of value, in turn, will affect ex ante incentives and thereby ex ante efficiency.

My analysis therefore begins by examining how various alternative rules affect bargaining between parties and, in turn, affect the ex post division of value. To illustrate these effects, note that, in the considered example, Factory would generally fare better if it had a property right to pollute rather than if Resort had a property right to enjoin its pollution. Suppose that Factory and Resort can freely bargain with one another, and suppose also that pollution would be efficient because the value to Factory of the pollution-causing activity exceeds the harm it imposes on Resort. Given easy ex post bargaining, both rules would result in Factory possessing the right to pollute. The rules would differ, however, in the distribution of value that they would produce between Factory and Resort.

If Factory had the property right, it could keep the full value of its pollution-producing activities to itself. By contrast, if Resort had the property right, Factory would not be able to capture fully the value of its pollution-producing activity. Resort would be able to extract some of this value in exchange for its consent to Factory's pollution.7

After identifying the distributive effects of alternative rules, the analysis will examine how these different distributions of value affect the ex ante investments that parties make. Consider the incentives for Factory to invest ex ante in enhancing the value it can derive from its activities. If Resort had a property right to enjoin Factory, Factory would invest too little because Resort's property right would enable it to extract part of the value created by Factory's ex ante investment. Because Factory can anticipate this need to share the value of its activity with Resort, it would not have incentives to invest optimally. In contrast, if Factory enjoyed a property right to pollute, it would not have to share with Resort any part of the value produced by its ex ante investment. Thus, granting a property right to Factory would en-

7. Likewise, if pollution were inefficient, any allocation of entitlements would result in no pollution, but different rules would produce different distributions of value. If Resort were granted the property right, it would not have to pay to induce Factory not to pollute, whereas if Factory received the property right, Resort would have to pay. 


\section{The Ex Ante View of the Cathedral}

courage it to invest ex ante. Indeed, for reasons to become clear later, were it granted a property right Factory would even tend to invest excessively.

Now suppose that Resort has an entitlement to a pollution-free river but with the weaker protection of a liability rule. In this case, Factory would still have an incentive to invest. Under this liability rule, Factory would pay Resort the (court-estimated) harm that its pollution inflicts on Resort, in the event that it is efficient for Factory to operate. As a result, Factory would retain the excess of the value of its activity over this harm, and Factory would thus fully capture any incremental increase in the value produced by ex ante investments. Consequently, Factory would have an incentive to invest at the efficient level.

Consider also the effects of the allocation of entitlements on Resort's incentives to invest ex ante in enhancing the value of its activities. As Factory would have had it been granted a property right, Resort would have strong incentives to invest, and indeed might even invest excessively, if it were granted a property right to pollution-free water. Providing Resort with the entitlement protected by a liability rule instead would not solve this problem of excessive investment. Indeed, as this Paper will later show, liability rule protection would lead Resort to make investments that would be excessive to a degree even greater than under a property right rule.

In addition to ex ante investments in enhancing the values of their respective activities, the analysis will also examine Factory's and Resort's ex ante investments in reducing the harm that would result in the event of conflicting use. Factory and Resort, for example, could make investments to eliminate or reduce their reliance on the river in case a conflicting use problem arises down the road. The choice of rule might therefore also affect these investments and the extent to which they converge on, or deviate from, the socially optimal level.

If Resort were granted the entitlement with liability rule protection, it would have no incentive to make any such potentially harmreducing investments. In this case, however, Factory would have an incentive to invest in harm-reduction at the socially optimal level. In contrast, giving a property right to either of the parties would provide each party with incentives to make some - but less than socially optimal - investments in harm reduction. 
The choice of legal rule thus involves a range of possible ex ante considerations. The optimal rule from an ex ante perspective depends on a balance of these considerations. This analysis will provide a framework for determining which allocations of entitlements would perform best from the perspective of ex ante efficiency. The framework provides us with the relevant factors to assess and consider in answering the two questions that, for any given context involving externalities, the law must resolve: (i) which party should get the entitlement; and (ii) what form of protection should be provided to this party?

The analysis in this Paper shows that, from the perspective of ex ante efficiency, liability rules are not generally superior to property rights. This conclusion is worth noting because the literature has identified certain ex post advantages that inhere in liability rules. The analysis also indicates that we may want to expand our menu of alternative rules and include liability rules based on supercompensatory or under-compensatory damages. Finally, the analysis identifies certain advantages that the use of government fines and taxes has in terms of inducing optimal ex ante investments.

Before proceeding, I should note that the analysis of this Paper is limited to the choice between property rules and liability rules as they apply to cases of harmful externalities. Calabresi and Melamed's article raised the question of why, in cases involving possessory interests, courts generally protect ownership with a property right rather than a liability rule. As Kaplow and Shavell have demonstrated, however, this protection-of-ownership context differs substantially from the harmful-externalities context.8 In another work, I carry out an ex ante analysis of the protection-of-ownership question. 9

The remainder of this Paper is organized as follows. Part II introduces the problem of externalities and conflicting uses and discusses the differences between ex post and ex ante perspectives. Part III analyzes the effects of alternative legal rules on the ex post division of

8. See generally Kaplow \& Shavell, supra note 3, at 757-83.

9. See Lucian A. Bebchuk, Ownership and Exchange (working paper, 2001) (unpublished manuscript, on file with author). 


\section{The Ex Ante View of the Cathedral}

value between parties. Part IV uses this analysis to identify and examine the effects of alternative rules on parties' ex ante investments and actions. Part V discusses the implications that ex ante considerations have for legal policy and the selection of legal rules. Part VI concludes.

\section{The Ex Post VieW OF THe CATHEDRAL}

\section{A. The Conflicting-Use Problem}

This Section specifies the nature of the question occupying both prior literature and this Paper alike: How do we resolve the extremely common situation in which uses of assets conflict - that is, in which the use of one asset imposes an externality on the use of another asset? For expositional convenience, the analysis will proceed with reference to a paradigmatic example. As will be apparent, however, the conclusions this Paper derives with respect to this paradigmatic case have general applicability to other cases of harmful externalities.

To continue with our example from the previous section, suppose again that an industrial factory, Factory, stands on a river upstream and a recreational resort, Resort, stands on the river downstream. The time is the year 2000. This constitutes the first point in time that, as described below, the problem of conflicting use of the river's water arises and must be resolved by the law. As is standard in the analysis of ex post problems, this Part assumes that all the elements characterizing the problem have been fixed: the parties already exist in their respective locations and face definable potential benefits and costs from using the river. The succeeding Parts will later relax this restrictive assumption.

The conflicting use problem arises because Factory might benefit from engaging in a certain activity that would affect the river's water in a way that might impose harm on Resort. I will refer to this use of the water by Factory as "polluting" the water, and I will denote the benefit that Factory would derive from the activity as $V_{F}$. Thus, if it did not pollute, Factory would lose $V_{F}$. For the purpose of this analysis, it does not matter whether Factory's particular activity represents the only activity available to Factory or whether it merely supplements additional activities that do not pollute the river. It matters only that this polluting activity would benefit Factory in the amount of $V_{F}$, which otherwise would not materialize. 
Further suppose that pollution of the river's water by Factory would reduce the value of one of Resort's activities. If the water remains free of Factory's pollution, Resort's activity would generate a value of $V_{R}$. If Factory pollutes the water, however, Resort's activity would generate only a value of $V_{R}-H$, where $H$ represents Resort's potential loss of profits from a decline in the prices it can charge, a decrease in the number of its patrons, or any other damage Resort would suffer due to the pollution.

Note that Resort can always shut down its activity altogether rather than operate suboptimally under pollution. Hence, if pollution would cause Resort a level of harm exceeding the value of its activity, Resort can simply cease to engage in the activity, thereby limiting itself to a loss of $V_{R}$. Accordingly, the harm Resort will suffer will never exceed $V_{R}$ and will always equal the lesser of $V_{R}$ and $H$. Again, for the purposes of our analysis it does not matter whether the activity in question constitutes Resort's sole activity or merely one among many; it only matters that Factory's pollution will damage one of Resort's activities in an amount equal to the lesser of $H$ and $V_{R}$.

We can view the scenario described above as one involving an externality problem. Factory "externalizes" part of the costs produced by its activity. This externality equals the amount by which Factory's activity reduces the value of Resort's activity and thus equals the lesser of $V_{R}$ and $H$. We can also refer to the problem as a conflictinguse problem. Both parties would benefit from "using" the water, but because the water can only be either polluted or unpolluted, both parties cannot simultaneously use the water to their maximum benefit. Thus, a conflict arises: one party desires to use the water in a way inconsistent with the other party's desired use.

I shall refrain from labeling Factory as the "injurer" or Resort as the "victim." Although convenient, these labels carry normative baggage because we tend to perceive of the "injurer" as the party that causes the conflicting-use problem. As Coase has taught us, however, we should view the problem as a priori symmetric, where both parties cause the conflicting-use situation. To be sure, but for Factory, Resort could use the unpolluted water to its own benefit. On the other hand, but for Resort, Factory could pollute the water to its own benefit just 


\section{The Ex Ante View of the Cathedral}

as well. Both parties thus contribute an essential element to the existence of the conflicting-use problem.

\section{B. The Efficient Ex Post Outcome}

The most efficient resolution of the conflicting-use problem is the outcome that would maximize total aggregate value given the structure of the situation and the values of $V_{F}, V_{R}$, and $H$. Accordingly, we should consider three possible efficient outcomes, depending on the relative values of these three variables, as Table 1 below depicts:

(i) Scenario FR. In this scenario, efficiency demands that both Factory and Resort engage in their respective activities; that is, Factory should pollute and Resort should continue its activity despite the pollution. This scenario arises whenever the following two conditions hold true: (i) the value that pollution brings to Factory exceeds the harm it causes Resort, $\left(V_{F}>H\right)$; but (ii) Resort still derives a positive value from its activity, despite the harm from pollution $\left(V_{R}>H\right)$.

(ii) Scenario F. In this scenario, efficiency demands that only Factory engage in its activity; that is, Factory should pollute, and Resort should shut down its harmed activity. This scenario arises whenever the following two conditions hold true: (i) the harm Resort would suffer exceeds the benefit it would gain if it engaged in its activity despite pollution $\left(V_{R}<H\right)$; but (ii) the benefit Factory receives from polluting exceeds the harm it causes Resort $\left(V_{F}>V_{R}\right)$. 
(iii) Scenario R. In this scenario, efficiency calls for only Resort to engage in its activity and for Factory to shut down. This scenario arises whenever both the harm to Resort caused by pollution and the value of Resort's activity exceed the value of the polluting activity to Factory $\left(H, V_{R}>V_{F}\right)$.

\begin{tabular}{||lccc||}
\hline \hline \multicolumn{4}{|l|}{ TABLE 1. THE THREE SCENARIOS } \\
\hline $\begin{array}{l}\text { Out- } \\
\text { come }\end{array}$ & $\begin{array}{c}\text { Factory Under- } \\
\text { takes Polluting } \\
\text { Activity? }\end{array}$ & $\begin{array}{c}\text { Resort Un- } \\
\text { dertakes Ac- } \\
\text { tivity? }\end{array}$ & $\begin{array}{c}\text { Total Social } \\
\text { Value }\end{array}$ \\
\hline$F R$ & Yes & Yes & $V_{F}+V_{R}-H$ \\
\hline$F$ & Yes & No & $V_{F}$ \\
\hline$R$ & No & Yes & $V_{R}$ \\
\hline
\end{tabular}




\section{The Ex Ante View of the Cathedral}

\section{Law's Choice: Calabresi and Melamed's Four Rules}

What legal rules should govern the conflicting-use problem? In analyzing this question, I will use the classification of alternative legal rules put forward by Calabresi and Melamed and subsequently followed by much of the literature.10 Under this classification, four alternative rules need to be considered:11

(i) Entitlement to Resort Protected by a Property Right (the RP rule). Under this rule, Resort has an entitlement to operate free of pollution under the protection of a property right. In this case, if Resort does not wish to allow Factory to pollute, Resort can secure an injunction against Factory (backed, if needed, by criminal sanctions).

(ii) Entitlement to Resort Protected by a Liability Rule (the RL rule). Under this rule, Resort again has an entitlement to operate free of pollution, but this time under the weaker protection of a liability rule. In this case, Factory may elect to pollute, but if it did, it would have to pay Resort a court-estimated amount for the harm caused to Resort.12

10. See Calabresi \& Melamed, supra note 1, at 1115-16; see also Frank I. Michelman, Pollution as a Tort: A Non-Accidental Perspective on Calabresi's Costs, 80 YALE L.J. 647, 670 (1971) (reviewing Guido CALABRESI, THE COSTS OF ACCIDENTS: A LEGAL AND ECONOMIC ANALYSIS (1970)).

11. Other writers have suggested additional rules. As will be clear to readers, the analysis of this paper can be extended to identify the ex ante effects of these additional rules. The additional rules that commentators have thus far suggested involve the use of options. See, e.g., Ian Ayres, The 1998 Monsanto Lecture: Protecting Property with Puts, 32 VAL. U. L. REV. 793 (1998) (reviewing the choice of rule within the put/call framework); Ayres \& Balkin, supra note 3, at 729-33 (discussing put options and the way these options might be auctioned); Krier \& Schwab, supra note 3, at 471 (envisioning a rule granting Factory the option to shut down its activity and collect damages from Resort); Saul Levmore, Unifying Remedies: Property Rules, Liability Rules, and Startling Rules, 106 YALE L. J. 2149, 2153-60 (1997) (suggesting expanded sets of rules); Ronen Avraham, Modular Liability Rules, Working Paper No. 01-003, Olin Center for Law and Economics, University of Michigan (analyzing a group of optionsbased. Mhes distinction between property rights and liability rules is not always clear either in theory or in practice. See Kaplow \& Shavell, supra note 3, at 756-57 (describing both types of rules as "members of a continuum of liability rules that 
Recall that this harm would equal the smaller of the harm resulting from the pollution and the lost value of Resort's activity in the absence of pollution - that is, the smaller of $H$ and $V_{R}$ - as Resort would always have the option of shutting down its activity.13

(iii) Entitlement to Factory Protected by a Property Right (the FP rule). Under this rule, Factory has an entitlement to pollute protected by a property right. Therefore, Factory will be free to pollute at its discretion.

(iv) Entitlement to Factory Protected by a Liability Rule (the FL rule). Under this rule, Factory again has an entitlement to pollute but this time under the weaker protection of a liability rule. In this case, Resort may still make Factory cease its polluting activity, but if it does so, Resort would have to pay Factory damages in an amount that equals the (court-estimated) harm caused to Factory as a result: the loss of the value $V_{F}$. Note that the $F L$ rule is rarely used in practice, perhaps due to the stringent informational requirements it imposes on courts. For the sake of completeness, however, I will include this rule in the analysis.14

Significantly, all of these rules differ in the informational requirements they impose on courts. Under both property rules, FP and $R P$, the court need only verify whether Factory pollutes the river. In contrast, under the $R L$ rule the court not only has to verify whether Fac-

differ merely in their level of damages"). That observation notwithstanding, I will follow Kaplow and Shavell and assume the classification to be clear-cut.

13. For the conditions under which Resort should mitigate its loss by shutting down the affected activity, see the discussion in Section III.B supra. For the purposes of this analysis, I will assume that the liability rule will include (as is standard) such a mitigation requirement, and that in setting damages the court would attempt to estimate this value.

14. But see Spur Indus., Inc. v. Del. E. Webb Dev. Co., 469 P.2d 700 (Ariz. 1972) (ordering a cattle feedlots operator to shut down, and the developer of a neighboring retirement community to indemnify the feedlots operator for the costs of moving or shutting down). See generally Krier \& Schwab, supra note 3, at 467-70 (discussing in detail the "paradox of rule four"). But see A. Douglas Melamed, Remarks: A Public Law Perspective, 106 YALE L. J. 2209 (1997) (arguing that "Rule 4" remedies are widely used in public law contexts). 


\section{The Ex Ante View of the Cathedral}

tory pollutes but also to estimate the harm produced by the pollution. 15 Moreover, under the $R L$ rule with a mitigation requirement, the court needs to verify both the value of operating Resort in the absence of pollution $\left(V_{R}\right)$ and the magnitude of harm caused when both parties operate $(H)$. The imperfect information of courts might therefore make it difficult to obtain ex post efficiency. To focus on the analysis of ex ante effects, however, I shall put aside these informational issues and assume for simplicity that courts can ex post accurately observe $H, V_{F}$, and $V_{R}$.

\section{Ex Post vs. Ex Ante Efficiency}

\section{From Ex Post to Ex Ante}

As already emphasized, prior work has largely focused on identifying the rule that would facilitate attainment of the ex post efficient outcome. Calabresi and Melamed started from the Coasean insight that, in a world of no transaction costs, the efficient outcome will always occur under any of the four rules.16 As Coase also pointed out, however, the presence of transaction costs may cause the outcome to depend on the initial allocation of entitlements.17

In light of this insight, Calabresi and Melamed stressed the importance of identifying the impediments to an ex post efficient outcome. Having identified these impediments, the efficient allocation of entitlements in any given case would be the one that would most likely attain the ex post efficient outcome.18 Much work has subsequently focused on this question.

The ex post view yields important insights, and the considerations that it has identified have much relevance for legal policymaking.

15. Likewise, under the $F L$ rule, the court would have to verify the value of Factory's forgone activity, $\mathrm{V}_{\mathrm{F}}$.

16. See Coase, supra note 4 , at 8.

17. Id. at 16 (stating that when transaction costs are high, "the initial delimitation of legal rights does have an effect on the efficiency with which the economic system operates").

18. See Calabresi \& Melamed, supra note 1, at 1106-11 (analyzing how different types of transaction costs affect the choice between property rights and liability rules.) 
Such an analysis, however, is significantly incomplete. An ex post analysis takes the payoffs of the parties in a conflicting use problem as given.19 In the context of our paradigmatic example, an ex post analysis would take as given the existence of Factory and Resort in the year 2000; their location along the river; and the potential costs and benefits that would arise from pollution or from its absence, which we have designated $V_{F}, V_{R}$, and $H$. With all these elements of the situation taken as given, the question to focus on is which legal rule would lead to the efficient ex post outcome.

These elements of the situation, however, might very well have arisen as a function of actions occurring at some point in the past, which in turn may well have been influenced by the legal rule the parties anticipated would govern should a conflicting-use problem arise in the future. As a result, the choice of legal rule has important ex ante effects. Before turning to a detailed analysis of these effects, however, I wish to make two general observations about consequences of incorporating such effects into the analysis.

\section{Ex Post Distribution Matters for Efficiency}

Clearly, the choice of legal rule can have significant distributive consequences, affecting how total value is divided between Factory and Resort. Prior work has recognized this effect that rules have on the final distribution of value. 20 This literature has generally taken the view, however, that these distributional consequences have no relevance for efficiency. Rather, in the standard ex post analysis, efficiency concerns only the achievement of the largest total pie, which would come with an efficient ex post outcome, regardless of the particular division of this total pie.

19. See generally Calabresi \& Melamed, supra note 1 ; Kaplow \& Shavell, supra note 3; Ayres \& Talley, supra note 3. Some of the authors that analyzed the ex post problem have also discussed the possibility of ex ante effects. See Ayres \& Talley, supra note 3, at 1085-86; Kaplow \& Shavell, supra note 3, at 738. But the primary focus of these works has been on the ex post perspective.

20. See, e.g., Calabresi \& Melamed, supra note 1, at 1098-1102; Polinsky, Resolving Nuisance Disputes, supra note 3 at 1089-92. 


\section{The Ex Ante View of the Cathedral}

To be sure, commentators have expressed different views on whether distribution should constitute an independent objective of legal policy. Calabresi and Melamed, for example, take the view that "difficult as wealth distribution preferences are to analyze, it should be obvious that they play a crucial role in the setting of entitlements." 21 In contrast, Kaplow and Shavell have taken the view that "concern about the distribution of income has no bearing on the choice between property rules and liability rules." 22 Nonetheless, writers have generally shared the view that, as far as efficiency is concerned, the ex post distribution of value does not matter. For example, although Calabresi and Melamed believe that the distributional consequences of the choice of legal rule should be given some weight in themselves, 23 they view these distributional consequences as irrelevant for the evaluation of this choice from the perspective of efficiency. 24

As the analysis of this Paper will show, however, once we take ex ante considerations into account, the distribution of the ex post value does make a difference to overall efficiency. The size of the total pie under the most efficient ex post outcome depends on the parties' ex ante actions and investments. These actions and investments, in turn, depend in part on the ex post distribution of value that the parties anticipate. Hence, total value - that is, the total size of the pie - depends not only on whether a legal rule reaches the efficient outcome in any given ex post situation, but also on which ex post situation the rule produces in the first place.

It is worth comparing the point under consideration to the claim made by some writers that value distribution might affect efficiency in

21. See. Calabresi \& Melamed, supra note 1, at 1098.

22. See Kaplow \& Shavell, supra note 3, at 744; see also Louis Kaplow \& Steven Shavell, Why the Legal System Is Less Efficient than the Income Tax in Redistributing Income, 23 J. LEGAL STUD. 667 (1994) (developing the argument that legal rules should not be used to redistribute income because redistributing through the income tax and transfer system would be superior).

23. Indeed, as mentioned earlier, Calabresi and Melamed consider distribution a legitimate objective of legal policy. See Calabresi \& Melamed, supra note 1, at $1098-1102,1110$.

24. Id. at $1093-98,1106-10$. 
that changes in the final distribution of wealth might also affect parties' relative valuations of an entitlement.25 In our example, for instance, it might be argued that $V_{F}, V_{R}$, and $H$ could themselves depend on the choice of legal rule because, by affecting the parties' final wealth, the choice of rule can affect the parties' valuation of different scenarios.

Although the point made by these writers and the point made in this section both imply that ex post distribution matters for efficiency, these two points very much differ. Note that these writers do not claim that ignoring distributional effects might lead to an inefficient conclusion. Rather, they claim only that the efficient outcome and efficient rule are often indeterminate. Thus, efficiency alone could not provide a basis for selecting between two equally efficient outcomes and the rules that underlie them. In contrast, the analysis of this Paper suggests that ignoring the ex ante effects of the final distribution of value might sometimes lead to the selection of a rule that would be unequivocally less efficient.

\section{The Choice of Rule Matters Even When Ex Post Bargaining Is Easy}

From the ex post perspective extensively applied by prior work, legal rules matter only when parties cannot easily bargain ex post. In the context of our example, this position implies that legal rules would

25. See e.g., W. Michael Hanemann et al., Willingness to Pay and Willingness to Accept: How Much Can They Differ, 81 AM. ECON. REV. 635 (1991); Elizabeth Hoffman \& Matthew L. Spitzer, Willingness to Pay vs. Willingness to Accept: Legal and Economic Implications, 71 WASH. U. L. Q. 59 (1993) (investigating evidence on the divergence between willingness-to-accept and willingness-to-pay measures of value and exploring the implications of the divergence for analysis in law and economics); Daniel Kahneman et al., Experimental Tests of the Endowment Effect and the Coase Theorem, 98 J. POL. ECON. 1325, 1329-42 (1990) (reporting experiments showing asking prices to be higher than offer prices); Mark Kelman, Consumption Theory, Production Theory, and Ideology in the Coase Theorem, 52 S. CAL. L. REV. 669, 678-95 (arguing that the price that a party is willing to pay to prevent a harm from happening might differ from the price the party will ask for allowing the harm to happen, and analyzing the implications of this phenomenon for the Coase theorem); Duncan Kennedy, Cost-Benefit Analysis of Entitlement Problems: A Critique, 33 STAN. L. REV. 387, 401-21 (1981) (same). 


\section{The Ex Ante View of the Cathedral}

matter only if, in the year 2000, Factory and Resort would find it difficult to bargain and reach an agreement once they confront the conflicting-use problem. For this reason, such work has directed its attention to cases in which ex post bargaining is difficult or even impossible.

Once ex ante considerations are taken into account, however, the choice of legal rule might matter greatly even where parties can easily bargain ex post. Supposing that, in the year 2000, Factory and Resort can successfully bargain, and thereby attain the ex post efficient outcome, under any legal rule. The choice of legal rule might nevertheless have substantial influence on the ultimate division of value between Factory and Resort and thus, in turn, substantial influence on Factory and Resort's ex ante incentives. As a result, even assuming the parties can easily bargain in the year 2000, alternative legal rules can substantially differ in their effects on overall efficiency.

I would like to stress that I do not, of course, take issue with the Coase theorem. In a world with no transaction costs at any point in time, parties will adopt contracts at an early stage to ensure that they make all their ex ante investments efficiently. Rather, I claim that the absence of transaction costs ex post can make ex post bargaining easy but does not ensure that bargaining is easy, and optimal investments are induced, ex ante. Thus, even in a world free of transaction costs, the choice of legal rule can matter in terms of efficiency. A truly Coasean, transaction-cost-free world would require freedom from transaction costs not only at the time in which the externality arises but also at any earlier point in time in which relevant investments and actions take place. 


\section{The Effect OF Rules on the Ex Post Division of VAlue}

Having made some general observations about ex ante considerations, I now turn to analyzing how the choice of rule affects ex ante actions and decisions. This Part will take the first step in this analysis by comparing alternative rules in terms of their effects on the ex post division of value. 26

To abstract away from the ex post problems extensively studied by prior literature, I will assume that the parties can easily, and indeed with no impediments whatsoever, bargain ex post. This implies, among other things, that bargaining involves neither transaction costs nor informational asymmetries.

In particular, I assume that each party knows not only its own benefits and costs associated with the entitlement, but also the other party's benefits and costs. Thus, Factory knows the values of $H$ and $V_{R}$, and Resort knows the value of $V_{F}$. Finally, I will assume that courts can accurately assess all the values relevant for implementing the rules under consideration. Under these conditions, the parties will always reach the efficient outcome under any one of the alternative rules. The division of value between the parties, however, will differ considerably among alternative legal rules.

For the ease of exposition, I make the simplifying assumption that the parties have equal bargaining power and therefore will share equally in any gains from mutual trade. This assumption will not affect our qualitative conclusions about ex ante effects, and it will be apparent to the reader that the analysis can be adjusted to accommodate different assumptions about the parties' relative bargaining power.

Below I will analyze bargaining and the distribution of value produced by it in each of the three scenarios identified in Section II.B: the

26. An analysis of the effects of property rights and liability rules on the division of value in disputes between patent-holders and second-stage inventors infringing on these patents is carried out in Mark Schankerman and Suzanne Scotchmer, Damages and Injunctions in Protecting Intellectual Property, 32 RAND J. ECON. 199 (2001). 


\section{The Ex Ante View of the Cathedral}

scenario in which it is efficient for both Factory and Resort operate, the scenario in which it is efficient for only Factory to operate, and the scenario in which it is efficient for only Resort to operate. Sections A through $\mathrm{C}$ will examine the division of value under each of these scenarios in turn.

\section{A. Scenario FR: Factory and Resort Should Both Operate}

In this scenario both Factory and Resort should operate. As mentioned earlier, this scenario arises whenever: (i) the value of Factory's pollution-producing activity exceeds the harm from the pollution to Resort, $V_{F}>H$; and (ii) the value of Resort's activity exceeds the harm from the pollution, $V_{R}>H$.

Under the $R P$ rule, Factory must secure Resort's consent to conduct its polluting activity. When pollution takes place, Resort's value from its own activity is reduced by $H$, but Factory obtains a value of $V_{F}$. The net social surplus created by pollution, then, equals $V_{F}-H$. In order to obtain Resort's consent, Factory would have to compensate Resort for its damages, $H$, as well as pay it part of this net surplus.

Therefore, under the assumption that the parties share equally in gains from trade, Factory would pay Resort for its harm, $H$, plus half the amount of $V_{F}-H$. The final division of value between the parties would thus occur as follows: Factory would net $0.5\left(V_{F}-H\right)$, and Resort would net $V_{R}+0.5\left(V_{F}-H\right)$. The property protection that Resort enjoys would enable it not only to recover compensation for the harm it suffers from pollution, but also to extract some of the surplus generated by Factory's activity.

Under the $R L$ rule, on the other hand, Factory could pollute the river without Resort's consent as long as it pays Resort damages in an amount that equals its harm, $H$. In the scenario under consideration, the benefit of pollution to Factory exceeds the harm that pollution causes Resort $\left(V_{F}>H\right)$. Thus, Factory would decide to pollute and compensate Resort for the harm, $H$. Factory, however, would not need to offer any of its own surplus value as a bribe for Resort's consent. The final division of value between the parties would therefore be as follows: Factory would net $V_{F}-H$, and Resort would net $V_{R}$. Under liability-rule protection, the parties would have no reason to bargain 
because Resort could not extract from Factory an amount exceeding $H$ but would reject any offer of payment below $H$.

Under the FP rule, the state would ensure that Factory would be free to operate and pollute. Because it is efficient for Factory to operate in the scenario under consideration, the parties would have no incentive to bargain for a reallocation of their entitlements; the entitlement would already reside with its highest-valuing owner. Thus, the final division of value between the parties would involve Factory's netting $V_{F}$ and Resort's netting $V_{R}-H$.

\section{TABLE 2. DIVISION OF VALUE IN SCENARIO FR}

Payments

\begin{tabular}{|lcccc|} 
Rule & $\begin{array}{c}\text { Made by Fac- } \\
\text { tory }\end{array}$ & $\begin{array}{c}\text { Value to } \\
\text { Factory }\end{array}$ & $\begin{array}{c}\text { Value to Re- } \\
\text { sort }\end{array}$ & Total Value \\
\hline$R P$ & $\begin{array}{c}H+0.5\left(V_{F}-\right. \\
H)\end{array}$ & $0.5\left(V_{F}-H\right)$ & $\begin{array}{c}V_{R}+0.5\left(V_{F}-\right. \\
H)\end{array}$ & $V_{F}+V_{R}-H$ \\
\hline$R L$ & $H$ & $V_{F}-H$ & $V_{R}$ & $V_{F}+V_{R}-H$ \\
\hline$F P$ & No Payment & $V_{F}$ & $V_{R}-H$ & $V_{F}+V_{R}-H$ \\
\hline$F L$ & No Payment & $V_{F}$ & $V_{R}-H$ & $V_{F}+V_{R}-H$ \\
\hline
\end{tabular}

Under an FL rule, Resort would have the right to prevent Factory from polluting if it pays Factory damages in the amount of $V_{F}$. In the scenario under consideration, however, the harm to Resort from pollution would be less than the value of pollution to Factory. Hence, Resort would prefer to operate under pollution and bear that harm rather than pay an even larger price to prevent Factory from polluting. In the final division of total value between the parties, Factory would net $V_{F}$, and Resort would net $V_{R}-H$. 


\section{The Ex Ante View of the Cathedral}

\section{B. Scenario F: Only Factory Should Operate}

In this scenario, it is efficient for Factory to operate and for Resort to shut down its activity. As noted earlier, this scenario arises whenever the following two conditions are satisfied: (i) the harm Resort would suffer exceeds the benefit it would gain if it engaged in its activity despite pollution, $V_{R}<H$; and (ii) the benefit Factory receives from polluting exceeds the harm it causes Resort, $V_{F}>V_{R}$.

Under the $R P$ rule, Resort would have a right to operate free of harm, which would provide Resort with a benefit of $V_{R}$. Given, however, that the value of pollution to Factory exceeds the value of operating free of pollution to Resort, $V_{F}>V_{R}$, Resort would "sell" its right to Factory and shut down its operations because the transaction would produce a surplus of $V_{F}-V_{R}$.

The payment that Factory would be expected to make to Resort would compensate Resort for its forgone benefits and, furthermore, would provide it with a fraction of the net surplus produced by the exchange. Under the assumption of equal sharing of surplus, Resort would end up netting $V_{R}+0.5\left(V_{F}-V_{R}\right)$, whereas Factory would end up netting $V_{F}-0.5\left(V_{F}+V_{R}\right)$.

Under the $R L$ rule, Factory would be able to operate without Resort's consent, provided only that Factory pay Resort damages equal to the harm suffered by Resort. Because it would be efficient for Resort to shut down its activity altogether in the presence of pollution, its damages would equal $V_{R}$. Whereas Resort would be compensated for the lost benefit from its potential activity, Resort would not be able to extract from Factory anything more than the expected damage award. The final division of value would provide Factory with a net value of $V_{F}-V_{R}$ and Resort with a net value of $V_{R}$.

Under the $F P$ rule, Factory would have the right to operate without paying any damages. Because it would indeed be efficient for Factory to operate, the parties would have no incentive to bargain over a reallocation of rights. Also, because the potential harm to Resort from pollution would exceed the potential value to Resort from its activity, Resort would shut down. The final division of value between the parties would thus provide Factory with a net value of $V_{F}$ and would provide Resort with nothing. 
Finally, under the FL rule, Resort would be able to prevent Factory from polluting - that is, Resort would have the power to force Factory to shut down its polluting activity - by paying Factory damages equal to the value of Factory's activity, $V_{F}$. However, because the value of Factory's activity exceeds the potential value of Resort's activity, $V_{F}>V_{R}$, Resort would prefer not to exercise this option and would shut down its own activity instead. The final division of value between the parties would therefore provide Factory with a net value of $V_{F}$ and would provide Resort no value whatsoever.

\begin{tabular}{||lcccc||}
\hline \multicolumn{4}{|l|}{ TABLE 3. DIVISION OF VALUE IN SCENARIO $F$} \\
\hline \hline Rule & $\begin{array}{c}\text { Payments Made } \\
\text { by Factory }\end{array}$ & $\begin{array}{c}\text { Value to } \\
\text { Factory }\end{array}$ & $\begin{array}{c}\text { Value to } \\
\text { Resort }\end{array}$ & $\begin{array}{c}\text { Total } \\
\text { Value }\end{array}$ \\
\hline$R P$ & $\begin{array}{c}V_{R}+0.5\left(V_{F}-\right. \\
\left.V_{R}\right)\end{array}$ & $\begin{array}{c}V_{F}-0.5\left(V_{F}+\right. \\
\left.V_{R}\right)\end{array}$ & $0.5\left(V_{R}+V_{F}\right)$ & $V_{F}$ \\
\hline$R L$ & $V_{R}$ & $V_{F}-V_{R}$ & $V_{R}$ & $V_{F}$ \\
\hline$F P$ & No Payment & $V_{F}$ & 0 & $V_{F}$ \\
\hline$F L$ & No Payment & $V_{F}$ & 0 & $V_{F}$ \\
\hline
\end{tabular}

\section{Scenario R: Only Resort Should Operate}

In this scenario, it is efficient for only Resort to operate. Factory should shut down its activity because the value of Factory's polluting activity would be smaller than both the harm to Resort from the resulting pollution and the value to Resort of its activity - that is, $V_{F}$ is lower than both $H$ and $V_{R}$.

Under the $R P$ rule, Factory would be allowed to operate only if it bought Resort's consent, and Resort would provide such consent only if it received compensation exceeding the damages that it would suffer from pollution, which would be either $H$ or $V_{R .27}$ Factory, on the

27. As described above, the net harm would equal $H$ if Resort could efficiently operate despite the pollution but would equal the entire value of Resort's operation, $V_{R}$, if it could not efficiently operate under pollution. 


\section{The Ex Ante View of the Cathedral}

other hand, would have no reason to offer a payment exceeding the value of its own activity, $V_{F}$. Because the value of Factory's polluting activity in the considered scenario does not exceed the damages the pollution causes Resort, the parties would have no incentive to bargain over the reallocation of rights. The final division of value between the parties would provide Factory with no value whatsoever and would provide Resort with a value of $V_{R}$.

Under the RL rule, Factory would be allowed to operate, but only at the cost of paying Resort's damages from pollution, which would be $H$ or $V_{R}$. Because the polluting activity yields so little value in the scenario under consideration, however, Factory would prefer to shut down its activity rather than pay such a high price. The final division of value between the parties would thus again provide Factory with no value, and Resort would again obtain the maximum value of its activity, $V_{R}$.

Under the FP rule, Factory would have the right to operate and pollute at its own discretion and without making any payment to Resort. Given that the polluting activity would yield less value than either the harm from pollution to Resort or the value of Resort's activity, Factory would prefer to sell its consent to refrain from polluting to the higher-valuing Resort. In this exchange, Factory would be able to extract a price equal to the value of its activity, $V_{F}$, plus a fraction of the net surplus produced by the exchange.

The size of this surplus would depend on the relative magnitudes of $H$ and $V_{R}$. In the case in which the value of Resort's activity exceeds the potential harm from pollution, $V_{R}>H$, it would be efficient for Resort to operate regardless of Factory's actions, and the damages to Resort from pollution would thus equal $H$. Accordingly, the net surplus from Factory's shutting down its activity would be $H-V_{F}$. Under the assumption of equal bargaining power, Resort would pay Factory for the forgone benefits of its polluting activity, $V_{F}$, plus half the net surplus, which would be $0.5\left(H+V_{F}\right)$. Resort in turn would end up with $V_{R}-V_{F}-0.5\left(H-V_{F}\right)$, an amount equal to $V_{R}-0.5\left(V_{F}+H\right)$.

Now suppose that the potential harm to Resort from pollution exceeds the value of Resort's activity, $H>V_{R}$. In this case, Resort would shut down whenever Factory operates. Thus, Factory's consent to refrain from polluting would produce a gain of $V_{R}$ for Resort and hence a net surplus of $V_{R}-V_{F}$. Under the assumption of equal bargaining 
power, Resort would again pay Factory for its forgone benefits, $V_{F}$, plus half the net surplus, which would now be $0.5\left(V_{R}+V_{F}\right)$. Factory would retain $V_{R}-V_{F}-0.5\left(V_{R}-V_{F}\right)$, an amount equal to $V_{R}-0.5\left(V_{R}+\right.$ $\left.V_{F}\right)$, for itself.

Finally, under the $F L$ rule, Resort would have the right to prevent Factory's pollution provided that Resort would pay Factory damages in an amount equal to the value of its forgone activity, $V_{F}$. In this case, Factory would not be able to extract from Resort any payment in excess of $V_{F}$ but, on the other hand, would have no reason to accept any offer of payment below $V_{F}$. The final division of value between the parties would therefore provide Factory with a net value of $V_{F}$ and Resort with a net value of $V_{R}-V_{F}$. 


\section{TABLE 4. DIVISION OF VALUE IN SCENARIO $R$}

\begin{tabular}{|lcccc||}
\hline Rule & $\begin{array}{c}\text { Payments Made } \\
\text { by Resort }\end{array}$ & $\begin{array}{c}\text { Value to Fac- } \\
\text { tory }\end{array}$ & Value to Resort & $\begin{array}{c}\text { Total } \\
\text { Value }\end{array}$ \\
\hline$R P$ & No Payment & 0 & $V_{R}$ & $V_{R}$ \\
\hline$R L$ & No Payment & 0 & $V_{R}$ & $V_{R}$ \\
\hline$F P$ & $V_{F}+0.5\left(H-V_{F}\right)$ & $0.5\left(V_{F}+H\right)$ & $V_{R}-0.5\left(V_{F}+H\right)$ & \\
& $\left(\right.$ if $\left.V_{R}>H\right)$ & $\left(\right.$ if $\left.V_{R}>H\right)$ & (if $\left.V_{R}>H\right)$ & \\
& or & or & or & $V_{R}$ \\
& $V_{F}+0.5\left(V_{R}-V_{F}\right)$ & $0.5\left(V_{F}+V_{R}\right)$ & $V_{R}-0.5\left(V_{F}+V_{R}\right)$ & \\
& $\left(\right.$ if $\left.V_{R}<H\right)$ & $\left(\right.$ if $\left.V_{R}<H\right)$ & (if $\left.V_{R}<H\right)$ & \\
\hline$F L$ & $V_{F}$ & $V_{F}$ & $V_{R}-V_{F}$ & $V_{R}$ \\
\hline
\end{tabular}

The analysis of this final scenario $R$ completes our comparison of the legal rules in terms of their ex post distributive consequences. As we have seen, alternative legal rules differ considerably in how total value is divided ex post. As we shall now examine, these differences in ex post division translate into different ex ante behavior as well.

\section{The Ex Ante EfFects of Alternative Rules}

This Part identifies and analyzes the effects of alternative rules on ex ante investments. Section A introduces ex ante investments into the analysis of the conflicting use problem. Sections B and C then analyze the effects of the four alternative rules on parties' ex ante investments in enhancing the values of their activities. Likewise, Section D analyzes the rules' effects on ex ante investment in harm reduction. Section $E$ then provides an overall comparison of the rules in terms of their ex ante effects. 


\section{A. Introducing Ex Ante Investments}

Following the literature on the conflicting-use problem ex post, we have thus far treated as constant the values defining the situation at hand: the potential value of Factory's activity, $V_{F}$; the potential value of Resort's activity, $V_{R}$; and the potential harm resulting from joint operation by the parties, $H$. These values, however, might have arisen as a function of the parties' actions at earlier points in time.

For example, the value of Resort's and Factory's activities, $V_{F}$ and $V_{R}$, might be a function of their ex ante decisions about the scope of their activities, their products or services, the number of employees, and their investments in their human capital. Similarly, the harm that would result from joint operation by Resort and Factory, $H$, might also be a function of their various actions and investments. For example, the magnitude of $H$ might depend on the extent to which Factory or Resort invested to reduce the reliance of their respective activities on the river's water.

I will therefore denote below as $x_{F}$ and $x_{R}$ the investments made by Factory and Resort respectively in enhancing the value of their respective activities. I will also denote below as $y_{F}$ and $y_{R}$ the investments in harm-reduction made by Factory and Resort respectively. I will assume that all these investments have the standard feature of diminishing marginal effectiveness, so that the marginal value enhancement or harm reduction that investments produce declines with each additional dollar invested.

Which ex post allocation of entitlements would provide the best incentives for the parties to make these ex ante investments? In examining this question, I will assume that courts cannot observe the level of ex ante investments and that the ex post allocation of entitlements thus cannot be made dependent on such investments.28 Furthermore, I will focus on a choice of rule from among the four legal rules that

28. This assumption is similar to the standard assumption made in the incomplete contracts literature that parties' ex ante investments are noncontractible. See, e.g., HART, FIRMS, CONTRACT, supra note 6. 


\section{The Ex Ante View of the Cathedral}

Calabresi and Melamed identified and that the literature and the preceding Parts have considered.

If the parties could negotiate ex ante - that is, prior to making their investments - they could adopt an arrangement that would govern the ex post allocation of entitlements. Even in such a case, it would be valuable for lawmakers to identify the optimal arrangement and provide it as the default arrangement. Moreover, in many situations where parties can be expected to bargain ex post with ease, bargaining ex ante might still be difficult or even impossible.

In particular, conditions necessary for easy bargaining, such as absence of informational asymmetries, might obtain ex post but not ex ante. Even when parties are ex post informed about each other's potential payoffs, they might not possess such information ex ante. For example, before the parties make their respective investments ex ante, Factory or Resort each might have some private information regarding the effectiveness of their own investments in enhancing the value of their respective activities. After those investments are made, and after the ex post situation crystallizes, the consequences might become apparent to the other side, but that might not have been the case ex ante. The presence of ex ante informational asymmetries might therefore impede ex ante bargaining and might make the choice of legal rule especially important.

Before proceeding to analyze how alternative rules affect ex ante investments, let me note two assumptions that I make for simplicity of exposition. First, I will assume that ex ante investments do not determine which of the three scenarios will occur.29 Which scenario eventually materializes will be assumed to depend on exogenous developments in the markets within which Factory and Resort operate. Ex ante investments will be assumed to influence parties' potential payoffs within each scenario, however.

Second, for simplicity of exposition, I will use specific numerical examples for the probabilities of the three scenarios. It will be clear, however, that the reasoning and qualitative conclusions of the analysis will apply equally to any other values that these probabilities

29. The three identified scenarios are those in which: it is efficient for both parties to operate $(F R)$; it is efficient for only Factory to operate $(F)$; and it is efficient for only Resort to operate $(R)$. See Section II.B supra. 
might take. Specifically, I will assume that the probability of scenario $F R$ (that is, the scenario in which it is efficient for both Factory and Resort to operate) equals $1 / 2$; that the probability of scenario $F$ (that is, the scenario in which it is efficient for only Factory to operate) equals $1 / 3$; and that the probability of scenario $R$ (that is, the scenario in which only Resort should operate) equals $1 / 6$.

\section{B. Investment by Factory to Enhance the Value of Its Activity}

1. The Optimal Investment Level

From a social point of view, a party should invest up to the point where marginal social benefit equals marginal social cost, such that one dollar of investment produces one dollar of expected social value. In our example, enhancement of $V_{F}$ will provide social value only in those scenarios, $F$ and $F R$, in which Factory will actually operate. Consequently, the social value of investing another dollar would equal the marginal increase in $V_{F}$ multiplied by the combined probability of scenarios $F$ and $F R$, which is $5 / 6(1 / 3+1 / 2)$ in our example. In other words, Factory should invest only up to the point where $5 / 6$ of the marginal increase in $V_{F}$ falls to one, because such investment in $V_{F}$ will actually produce a benefit with a probability of only 5/6.30 As I will now turn to show, however, the Factory's private calculus for its investment in $V_{F}$ might diverge from the socially optimal calculus, and as a result Factory will invest too much or too little in enhancing the value of its activity.

\section{Investment under Alternative Rules}

a. Entitlement to Resort with Property-Right Protection. As Part III demonstrated, if Resort is given the entitlement with property-right protection, then Resort will be able to extract value from Factory whenever it is efficient for Factory to pollute. Thus, under an $R P$ rule in both scenarios $F R$ and $F$, Resort will allow Factory to operate in

30. This means that the socially optimal investment $x$ satisfies $5 / 6 x V_{F}^{\prime}(x)=1$. More generally, if $P_{F}$ and $P_{F R}$ denote the probabilities of scenarios $F$ and $F R$, respectively, then the optimal investment $x$ will satisfy $\left(P_{F}+P_{F R}\right) x V_{F}^{\prime}(x)=1$. 


\section{The Ex Ante View of the Cathedral}

exchange for part of the value of Factory's activity. Assuming that the parties enjoy equal bargaining power, we have concluded in Section III that, in scenarios $F R$ and $R$, Factory will capture half of any marginal increase in the value of its activity, $V_{F}$.

We can now consider Factory's private calculus as to how much to invest ex ante. Factory will, of course, bear the full cost of every dollar of marginal increase in its investment, $x_{F}$. Factory will benefit from a marginal increase in the value of $V_{F}$, however, only in scenarios $F$ and $F R$, which have a combined probability of $5 / 6$. Moreover, even in those scenarios Factory will capture only half of the marginal increase in value.

It follows that Factory will have no incentive to invest beyond the point where 5/12 of the resulting marginal increase in $V_{F}$ produced by an additional dollar of investment falls to one.31 This implies that Factory will set its level of investment, $x_{F}$, below the socially optimal level because it can expect that Resort will capture half of the return produced by its investment. Stated more intuitively, under the $R P$ rule Factory will bear the full cost of increasing $x_{F}$ but will capture only half of the resulting social benefits. For this reason, Factory's incentives to invest will be less than socially optimal, and it will invest too little. 32

b. Entitlement to Resort with Liability-Rule Protection. If Resort receives the entitlement but with only liability-rule protection, Factory will have to pay damages to Resort in scenarios $F$ and FR. Recall, however, that these payments of damages to Resort ( $H$ in scenario $F R$ and $V_{R}$ in scenario $F$ ) will not depend on the value of Factory's activity, $V_{F}$.

31. Formally, Factory's investment under the rule would satisfy 5/6 $\times 1 / 2 x$ $V_{F}^{\prime}(x)=1$. More generally, let us assume that the bargaining between the parties will result in Resort's capturing a fraction $\phi$ of the surplus and Factory's thus capturing a fraction $(1-\phi)$ of the surplus. Under this more general assumption, Factory's investment would satisfy $\left(P_{F}+P_{F R}\right) x(1-\phi) x V_{F}^{\prime}(x)=1$.

32. This result resembles the standard result in the analysis of a hold-up problem: when the value that a party $A$ produces can be expected to become subject to a hold-up by party $B$, party $A$ will underinvest in enhancing this value. See, e.g., HART, FIRMS, CONTRACTS, supra note 6, at 39-42. 
Consider Factory's private calculus as to how much to invest ex ante under this rule. Again, Factory will bear the full cost of every dollar of marginal increase in its investment, $x_{F}$, and will benefit from any resulting increase in $V_{F}$ only with a probability of $5 / 6$, the combined likelihood of scenarios $F$ and $F R$. Unlike the $R P$ rule, however, the $R L$ rule will allow Factory to capture the full $5 / 6$ of marginal increase in $V_{F}$. Because Factory's payment to Resort under the $R L$ rule will not depend on the value of $V_{F}$ (and thus will not depend on marginal increases in $V_{F}$ ), in scenarios $F$ and $F R$ Factory will capture any marginal increase in $V_{F}$. Therefore, Factory will invest up to the point where $5 / 6$ of the marginal increase in $V_{F}$ falls to one.33

This conclusion implies that, under the $R L$ rule, Factory will invest at the socially optimal level. Because the payment that Resort will receive from Factory will not vary with the value of Factory's activity, $V_{F}$, Factory will be the "residual claimant" that captures the full value of marginal increases in $V_{F}$. As a result, Factory's private incentives will lead it to set its investment in value enhancement at the socially optimal level.

c. Entitlement to Factory with Property-Right Protection. Granting Factory an entitlement with property-right protection will enable it to capture value not only in scenarios $F$ and $F R$ but also in scenario $R$, in which it is efficient for Factory to shut down its activity. In scenario $R$ Factory will be able to extract a payment from Resort in return for not polluting and thus not causing damage to Resort. As Section III.C showed, in scenario $R$ Factory will receive an amount equal to $V_{F}$, the amount Factory would be giving up by shutting down its polluting activity, plus, under the assumption of equal bargaining power, half of the potential loss that Resort would avoid by Factory's shutting down. This potential loss would be equal to the lesser of $\left(H-V_{F}\right)$ or $\left(V_{R}-V_{F}\right)$. Thus, Factory would get an amount equal to $V_{F}$ plus half of the higher of $\left(H-V_{F}\right)$ and $\left(V_{R}-V_{F}\right)$, or, equivalently, half of $V_{F}$ plus half of the higher of $H$ and $V_{R}$.

33. Formally, Factory's investment under the rule would satisfy $5 / 6 x V_{F}^{\prime}(x)=$ 1 , which is the condition defining the socially optimal level of investment. See supra note 30. More generally, Factory's investment would satisfy $\left(P_{F}+P_{F R}\right) x$ $V_{F}^{\prime}(x)=1$. 


\section{The Ex Ante View of the Cathedral}

Now consider Factory's private calculus under the FP rule as to how much to invest ex ante. As always, Factory will bear the full cost of every marginal increase in its investment. Factory will also capture the full value of its activity, $V_{F}$, in scenarios $F$ and $F R$, which have a combined probability of $5 / 6$. Finally, in scenario $R$, in which it would be efficient for Factory to shut down, Factory would still gain an amount equal to half of $V_{F}$ plus half of the higher of $H$ and $V_{R}$. Thus, on the whole Factory will make an expected gain of 11/12 of each additional increase in $V_{F}$. Factory therefore will invest up to the point where the marginal increase in $V_{F}$ produced by an additional dollar of investment falls to $11 / 12.34$

Recall, however, that Factory's socially optimal level of investment is at the point where 5/6 of the marginal increase in $V_{F}$ falls to one dollar. It follows that Factory will adopt under the FP rule an excessive - that is, higher than socially optimal - level of investment, $x_{F}$. Because Factory would be able to obtain benefit from an increase in $V_{F}$ even in scenario $R$, in which Factory's activity would shut down and produce no social value, Factory will obtain from its investment some extra private benefits that will not reflect social gain. This divergence between the private and social calculus will lead Factory to invest excessively.35

34. Formally, Factory's actual investment would satisfy $[5 / 6+(1 / 6 x 1 / 2)] x$ $V_{F}^{\prime}(x)=1$. More generally, relaxing the assumption of equal bargaining power, Factory's investment would satisfy $\left(P_{F}+P_{F R}+\phi P_{R}\right) x V_{F}^{\prime}(x)=1$.

35. This result is similar to those in the law and economics literature showing that, in some contexts, compensating a party for a value that is not going to be in fact realized might lead to overinvestment. For example, Steven Shavell has shown that the expectation damages remedy in contracts will lead to overinvestment in reliance because the relying party will disregard the contingency in which her investment would not produce social value but in which she would be compensated for it by the other side. See Steven Shavell, Damage Measures for Breach of Contract, 11 BELL J. ECON. 466 (1980). Similarly, articles by Robert Cooter and by Louis Kaplow have suggested that full compensation for government takings leads to overinvestment because parties will disregard the possibility that their investments might not produce social value if their property is taken by the government. See Louis Kaplow, Economic Analysis of Legal Transition, 99 HARV. L, REV. 509 (1986); Robert Cooter, Unity in Tort, Contract, and Property: The Model of Precaution, 73 CAL. L. REV. 1 (1985). 
d. Entitlement to Factory with Liability-Rule Protection. Let us now turn to the rule that also gives the entitlement to Factory but with only liability-rule protection. Under this rule, Factory would again be able to capture value not only in scenarios $F$ and $F R$ but also in scenario $R$, in which it would shut down its activity (as efficiency requires). In scenario $R$ Resort would be able to make Factory shut down but would have to pay Factory the value of its forgone activity, $V_{F}$. Thus, under liability-rule protection, Factory will capture the full return from any marginal increase in the value of its activity in all scenarios.

Turning to Factory's private calculus, observe that, as under all other rules, Factory will bear the full cost of every dollar of marginal increase in its investment. Under the FL rule, however, Factory will also capture the resulting marginal increase in the value of $V_{F}$ in every scenario, including scenario $R$, in which the increase in the value of $V_{F}$ would produce no social value. Thus, Factory will continue to invest all the way down to the point where the total increase in $V_{F}$ from an additional dollar of investment falls to one dollar. 36

This level of Factory investment will clearly exceed the socially optimal level. Furthermore, under the FL rule Factory would capture in scenario $R$ the full marginal increase in the value of $V_{F}$, whereas under the FP rule Factory would capture in this scenario only half of this increase in the value of $V_{F}$. Thus, the FL rule would distort Factory's incentives even more severely in the direction of excessive investment than would the FP rule. 37

36. Formally, Factory's investment under the rule would satisfy $V_{F}^{\prime}(x)=1$.

37. Under the FL rule Factory may appear to net a lesser share of the total value created than under the FP rule. As a consequence, Factory would also appear at first glance to have less of an incentive under the $F L$ rule than under the $F P$ rule to invest in $V_{F}$. The $F L$ rule, however, provides a stronger incentive on the margin to increase $V_{F}$. Under the FL rule, Factory will capture in scenario $R$ the full value of any increase in the value of $V_{F}$. In contrast, under the $F P$ rule, Factory would in this scenario get a large value on the whole but this value will go up with an increase in $V_{F}$ by only half of the amount of increase. The reason is that, under the FP rule, Factory would get in scenario $R$ half of the surplus created by its agreement with Resort, in addition to getting $V_{F}$. Because increasing $V_{F}$ would reduce this surplus, this extra element of value would operate to mitigate the incentive to invest excessively in increasing $V_{F}$. 


\section{The Ex Ante View of the Cathedral}

\section{Resort's Ex Ante Investment to Enhance the Value of Its Activity}

\section{The Optimal Investment Level}

As already noted, from a social point of view, a party should invest only up to the point where the marginal expected social value from additional investment falls to its marginal cost. Increasing the value of $V_{R}$ would produce a social benefit only in scenarios $R$ and $F R$, and it would produce no social value in scenario $F$, in which Resort would shut down its activity. Accordingly, the social value of investing another dollar would equal the resulting marginal increase in the value of $V_{R}$ multiplied by the combined probability of scenarios $R$ and $F R$, which equals $2 / 3$ in our example $(1 / 6+1 / 2)$.

Resort should invest, then, up to the point where $2 / 3$ of the marginal increase in the value of $V_{R}$ produced by an additional dollar of investment falls to one dollar.38 As we shall presently see, however, Resort's private calculus would differ from the social calculus under some of the alternative rules, and therefore Resort would under these rules inefficiently invest in enhancing the value of its activity.

\section{Investment under Alternative Rules}

a. Entitlement to Resort with Property-Right Protection. Granting the entitlement to Resort with property-right protection would enable Resort to capture value not only in scenarios $R$ and $F R$ but also in scenario $F$, in which Resort would shut down its activity. In this scenario, in return for allowing Factory to operate, Resort would be able to extract from Factory a payment equal to $V_{R}$, Resort's loss from shutting down its activity, plus half of $V_{F}-V_{R}$, the surplus produced by the exchange. 39

Now consider Resort's private calculus as to how much to invest ex ante. As always, Resort will bear the full cost of each additional dollar

38. This means that the socially optimal investment must satisfy $2 / 3 x V_{R}^{\prime}(x)$ $=1$. More generally, if $P_{R}$ and $P_{F R}$ denote the probabilities of scenarios $R$ and $F R$ respectively, then the optimal investment will be defined by $\left(P_{R}+P_{F R}\right) x V_{R}^{\prime}(x)=$ 1 .

39. The net value that Resort will obtain under the $R P$ rule in scenario $F$ thus equals $0.5\left(V_{R}+V_{F}\right)$. See Section III.C supra. 
of investment in enhancing the value of its activity. Resort will also benefit from the full value of $V_{R}$ in scenarios $R$ and $F R$, which have a combined probability of $2 / 3$. Furthermore, in scenario $F$, which has a probability of $1 / 3$, Resort's value will increase by half of any marginal increase in the value of $V_{R}$.

It follows that Resort will have an incentive to invest up to the point where $5 / 6(2 / 3+[1 / 2 \times 1 / 3])$ of the marginal increase in the value of $V_{R}$ produced by an additional dollar of investment falls to one dollar.40 By contrast, the socially optimal level of investment for Resort is, as was noted above, at the point where only $2 / 3$ of the marginal increase in $V_{R}$ falls to one dollar.

The above implies that the level of investment chosen by Resort will be higher than socially optimal. Essentially, increases in the value of $V_{R}$ would provide Resort with some private benefit that would not reflect a social gain but merely a transfer of value from Factory. Because additional investment would produce for Resort private benefits exceeding the social benefits produced, Resort will invest excessively under the $R P$ rule.

b. Entitlement to Resort with Liability-Rule Protection. Under the rule that gives the entitlement to Resort with liability-rule protection, Resort will again obtain value not only in scenarios $R$ and $F R$ but also in scenario $F$, in which it would not operate. In scenario $F$, Resort would shut down its activity but it would receive from Factory compensation for the value of its forgone activity, $V_{R .41}$ Thus, as discussed in on III, under the RL rule Resort will capture the full value of $V_{\Lambda} \ldots$ all three scenarios.

Turning to Resort's private calculus, observe that Resort will again bear the full cost of every dollar of marginal increase in its investment. Under the considered rule, however, Resort will obtain a benefit equal

40. Formally, Resort's investment under the rule would satisfy $[4 / 6+(1 / 2 x$ $1 / 3)] x V_{R}^{\prime}(x)=1$. More generally, Resort's investment would satisfy $\left[P_{R}+P_{F R}+\right.$ $\left.(1-\phi) x P_{F}\right] x V_{R}^{\prime}(x)=1$.

41. By hypothesis, only Factory should operate in scenario $F$. Thus, under the $R L$ rule, the damages that Factory would pay to Resort in scenario $F$ would equal $V_{R}$. Resort would receive this payment and willingly shut down. See also Section III.B supra. 


\section{The Ex Ante View of the Cathedral}

to marginal increase in the value of $V_{R}$ in all three scenarios, including scenario $F$, in which the increase in value of $V_{R}$ would produce no social value. Resort thus will elect to invest up to the point where the marginal increase in the value of $V_{R}$ produced by an additional dollar of investment falls to one dollar.42

This level of investment will clearly exceed the socially optimal level. Essentially, Resort's private gains from enhancing the value of $V_{R}$ would exceed the social gains from such an increase. Furthermore, under the $R L$ rule Resort would capture the full value of any marginal increase in the value $V_{R}$, whereas under the $R P$ rule Resort would capture only a fraction of the increase in this value of $V_{R} .43$ Hence, the $R L$ rule would distort Resort's incentives in the direction of excessive investment even more severely than the $R P$ rule would.

c. Entitlement to Factory with Property-Right Protection. Under the FP rule Factory's property right will enable it to extract value from Resort in scenario $R$. In this scenario, in which it would be efficient for only Resort to operate, Factory would agree to shut down its activity in exchange for compensation from Resort. 44

Furthermore, in the case in which pollution would be too costly for Resort to bear and operate - that is, the case in which $V_{R}<H-$ how

42. Formally, Resort's investment under the rule would satisfy $V_{R}{ }^{\prime}(x)=1$.

43. Note that, whereas Resort's total gain under the $R P$ rule may exceed that under the $R L$ rule, Resort's incentive to invest in raising the value of its activity under the $R L$ rule is stronger on the margin than under the $R P$ rule.

44. Recall that the entitlement that Factory would enjoy represents the freedom to engage in its activity, i.e., to pollute the river. Consequently, Factory can transfer the entitlement and thereby extract value from Resort only if Factory completely shuts down its polluting activity. This can occur only in scenario $R$, in which Factory should shut down its activity anyway. In scenario FR, Factory would not be willing to shut down its activity and thus could not transfer its entitlement and extract value from Resort, whether under the FP rule or the $F L$ rule. By contrast, the entitlement that Resort would enjoy represents simply the freedom from pollution, such that transfer of the entitlement would not require Resort to shut down its activity but merely to suffer simultaneously the presence of pollution. Thus, granting the entitlement to Resort with property-right protection would enable it to extract value from Factory not only in scenario $F$, in which Resort would shut down, but also in scenario FR, in which Resort would continue to operate despite the pollution. 
much Factory will be able to extract would depend on the value of $V_{R}$. In this case, under the assumption of equal bargaining power, both Resort and Factory in scenario $R$ will capture half of any marginal increase in the value of Resort's activity.

Turning to Resort's private calculus as to how much to invest ex ante, we start by noting that Resort will, as always, bear the full cost of any marginal increase in its investment. In scenario $F R$, which has a probability of $1 / 2$, Resort would also benefit from the entire marginal increase in the value of $V_{R}$. In scenario $R$, however, which has a probability of $1 / 6$, Resort would capture only half of the marginal increase in the value of $V_{R}$. Thus, Resort will have an incentive to invest only up to the point where $7 / 12(1 / 2+[1 / 6 \times 1 / 2])$ of the marginal increase in the value of $V_{R}$ produced by an additional investment of one dollar falls to one. 45

This means that Resort will set its level of investment below the socially optimal level. The underlying intuition is that, under the $F P$ rule, Resort will bear the full cost of increasing $x_{R}$ but will capture only part of the resulting benefits. The remainder of the expected benefits that Resort's investment will produce will go to Factory. For this reason, Resort will have an incentive to invest less than would be socially optimal.

d. Entitlement to Factory with Liability-Rule Protection. Under the FL rule, Resort will be forced to pay damages to Factory in scenario $R$, in which it would be efficient for Factory to shut down its activity. Resort's payment in scenario $R$, however, would equal the forgone value of Factory's activity and would not depend on the value of Resort's activity. Thus, Factory would not be able to extract from Resort any portion of marginal increase in $V_{R}$ produced by Resort's ex ante investment.

Consider now Resort's private calculus as to how much to invest ex ante under this rule. Resort will bear the full cost of any marginal increase in its investment, and Resort will also capture fully in scenarios

45. Formally, Resort's investment under the rule would satisfy $7 / 12 x V_{R}^{\prime}(x)=$ 1. More generally, relaxing the assumption that $V_{R}<H$, Resort's investment would satisfy $\left[P_{F R}+P_{R} x(1-\alpha x(1-\phi))\right] x V_{R}^{\prime}(x)=1$, where $\alpha$ denotes the probability that $V_{R}<H$. 


\section{The Ex Ante View of the Cathedral}

$R$ and $F R$, which have a combined probability of $2 / 3$, any marginal increases in the value of $V_{R}$. Therefore, Resort will invest up to the point where $2 / 3$ of the marginal increase in the value of $V_{R}$ falls to one dollar. 46

This conclusion implies that, under the $R L$ rule, Resort will invest at the socially optimal level. Essentially, Factory would be able to extract in scenario $R$ some payment from Resort, but this payment would not vary with the value of $V_{R}$. Therefore, Resort would still receive in this scenario the excess of $V_{R}$ over the damages payments made to Factory and would thus be the "residual claimant." Because Resort would capture the full expected social benefit from its investment in enhancing the value of its activity, its private investment incentives would align with those that are socially optimal.

e. Comparing the Rules. We can now put together our conclusions concerning how alternative rules would affect Factory and Resort's investments in enhancing the values of their respective activities. Table 5 summarizes how Resort and Factory's investments under the alternative rules would compare with the socially optimal levels.

46. Formally, Resort's investment under the rule would satisfy $4 / 6 x V_{R}{ }^{\prime}(x)=$ 1 , which is the condition defining the socially optimal level of investment. See note XXX supra. 


\section{TABLE 5. VALUE-ENHANCING INVESTMENTS UNDER ALTERNATIVE RULES}

\begin{tabular}{|lcc|}
\hline Rule & $\begin{array}{c}\text { Factory's Investment in } \\
\text { Enhancing } V_{\boldsymbol{F}}\end{array}$ & $\begin{array}{c}\text { Resort's Investment in } \\
\text { Enhancing } V_{\boldsymbol{R}}\end{array}$ \\
\hline$R P$ & Suboptimal & Excessive \\
\hline$R L$ & Optimal & Most Excessive \\
\hline$F P$ & Excessive & Suboptimal \\
\hline$F L$ & Most Excessive & Optimal \\
\hline
\end{tabular}

As the above table indicates, none of the four rules can simultaneously induce the optimal level of both $x_{F}$ and $x_{R}$. Each one of the two property-right rules, $R P$ and $F P$, would lead both parties to invest inefficiently, with the party receiving the entitlement investing excessively and the other party investing suboptimally. Each one of the two liability rules, $R L$ and $F L$, would lead the party receiving the entitlement to invest optimally, but the other party would invest excessively - and to a greater extent than in the case in which the party receiving the entitlement was given property-right protection.

\section{Ex Ante Investments in Harm Reduction}

\section{Optimal Investment Levels}

Having examined how alternative legal rules affect parties' investments in enhancing the value of their activities, I now turn to considering how these rules affect the parties' ex ante investments, $y_{R}$ and $y_{F}$, in reducing the magnitude of the potential harm to Resort, $H$, in the event of joint operation. From a social point of view, each party should invest in harm reduction up to the point where the expected social benefit from an additional dollar of such investment falls to one dollar.

In determining marginal social benefit, we must take into account that the potential harm would actually occur only in scenario $F R$, which has a probability of $1 / 2$. Thus, the expected social benefit from reducing the value of $H$ is equal only to half of this reduction. Hence, 


\section{The Ex Ante View of the Cathedral}

it would be socially optimal for Factory to invest up to the point where $1 / 2$ of the marginal reduction in $H$ produced by an additional dollar of investment by Factory is equal to one dollar. 47 Similarly, from a social point of view, Resort should invest up to the point where $1 / 2$ of the marginal reduction in $H$ produced by an additional dollar of investment by Resort is equal to one dollar.48

\section{Investment under Alternative Rules}

a. Entitlement to Resort with Property-Right Protection. Let us start with Factory's investment in harm reduction under the $R P$ rule. Under this rule, only in scenario $F R$, in which the harm would actually occur, will Factory make a payment to Resort to get its permission for Factory's activity, and Factory will consequently capture a value of $0.5 V_{F}-0.5 H .49$ Thus, should scenario FR occur, Factory would capture half of the savings from any marginal reduction in $H$.

Accordingly, when Factory considers how much to invest, it will recognize that its expected benefit from increasing $y_{F}$ by one dollar equals $1 / 4(1 / 2 \times 1 / 2)$ of the marginal reduction in the value of $H$ produced by such an investment. Thus, Factory will invest up to the point where $1 / 4$ of the reduction in the value of $H$ produced by an additional dollar investment falls to one.

It follows that Factory's level of investment in harm reduction will fall below its socially optimal level. The intuition behind this conclusion is that, although Factory will bear the full cost of any marginal increase in $y_{F}$, it will share with Resort the expected benefits from such investment, that is, the savings in scenario $F R$ from a reduction in the value of $H$. As a result, compared with what would be socially optimal, Factory will invest too little.

47. Formally, Factory's optimal level of investment in harm reduction would be defined by $1 / 2 \times H y_{F}^{\prime}(y)=-1$. More generally, Factory's optimal level of investment in harm reduction would satisfy: $P_{F R} x H y_{F}^{\prime}(y)=-1$.

48. Formally, Resort's optimal level of investment in harm reduction would satisfy: 1/2 $x H y_{R}{ }^{\prime}(y)=-1$. More generally, Resort's optimal level of investment in harm reduction would satisfy: $P_{F R} x H y_{R}{ }^{\prime}(y)=-1$.

49. See Section III.A supra. 
For similar reasons, Resort will also invest suboptimally in harm reduction under the $R P$ rule. The harm will affect Resort also only in scenario $F R$, and Resort would be able to capture in this scenario only half of the benefits from reducing the value of $H$. Thus, Resort will invest up to the point where $1 / 4$ of the marginal reduction in $H$ produced by an additional dollar investment by Resort falls to one. Thus, because Resort will bear the full costs of increasing its investment in harm reduction but will share the expected benefits of such reduction with Factory, Resort will invest too little compared with what would be socially optimal.

b. Entitlement to Resort with Liability-Rule Protection. Under the RL rule, which gives Resort the entitlement with liability-rule protection, Factory will pay Resort damages in the amount of $H$ should the harm actually materialize, that is, in scenario $F R$. Thus, in this scenario, which has a probability of $1 / 2$, Factory would capture all the savings from a reduction in the value of $H$. Using reasoning similar to that used earlier, we can conclude that Factory will invest up to the point where $1 / 2$ of the reduction in $H$ resulting from an additional dollar of investment is equal to one.

It follows that Factory will invest optimally in harm reduction. Essentially, under the $R L$ rule Factory will both bear the full social costs of a marginal increase in its investment level and capture the full expected social benefits resulting from such investment.

In contrast, Resort's level of investment in harm reduction will be zero and thus clearly suboptimal. This inefficiency arises because in scenario $F R$, in which the harm $H$ would actually occur, Resort would receive full compensation from Factory. Hence, Resort will not get any benefit from reducing the value of $H$ and thus will have no incentive whatsoever to invest in lowering the value of $H .50$

c. Entitlement to Factory with Property-Right Protection. Under the FP rule, which gives the entitlement to Factory with property-right pro-

50. This result is similar to one from an economic analysis of torts: when courts make injurers strictly liable for victims' losses, injurers will invest optimally in precautions and victims will make no investment in precautions. See, e.g., STEVEN SHAVELL, ECONOMIC ANALYSIS OF ACCIDENTS, ch. 2 (1987). 


\section{The Ex Ante View of the Cathedral}

tection, Factory will make no payments to Resort in scenario $F R$, in which the harm $H$ would materialize. Thus, Factory's payoff in scenario $F R$ will not depend on the value of $H$. Indeed, under certain conditions an increase in $H$ would in fact benefit Factory by increasing the amount that Factory would be able to extract from Resort in scenario R.51

Factory thus would have no incentive to make any ex ante investment in harm reduction. A zero level of investment in harm reduction by Factory will clearly fall below the socially optimal level. The problem is that, although Factory would bear the full cost of any investment it would make in harm reduction, it would derive none of the social benefits produced and, indeed, might even lose money from the resulting decrease in $H$.

In contrast, Resort will invest excessively in harm reduction under the $F P$ rule. In scenario $F R$, Resort would obtain no payment from Factory and would therefore bear the full cost of the harm. Furthermore, in scenario $R$, in which Factory would agree to shut down its activity and the potential harm would not materialize, a smaller value of $H$ would improve Resort's bargaining position and reduce the amount that Resort would have to pay Factory in return for its shutting down its activity. 52

In considering how much to invest, Resort would take into account the benefit that it would obtain from a reduction in $H$ in both scenario $F R$, where Resort's private benefit would reflect social benefit, and scenario $R$, where Resort's private benefit would not reflect a social benefit but rather a transfer from Factory. Thus, because Resort will derive private benefits exceeding the social benefits from investment in harm reduction, Resort will invest excessively.

51. Specifically, an increase in $H$ will increase Factory's expected value in scenario $R$ if $V_{R}>H$. In that situation, a larger $H$ means that Factory would save Resort even more money by shutting down its activity. Resort would therefore have a larger surplus to split with Factory. See Section III.C supra.

52. Stated differently, reducing the value of $H$ might decrease the amount that Factory would be able to extract in return for shutting down its activity in scenario $R$. Specifically, a decrease in $H$ would reduce the expected payment that Resort would make to Factory in scenario $R$ if $V_{R}>H$. See Section III.C supra. 
d. Entitlement to Factory with Liability-Rule Protection. Finally, under the FL rule, which gives the entitlement to Factory but with the protection of only a liability rule, Factory will in all three scenarios obtain the full value of its activity, $V_{F}$. Thus, Factory's final value will in no way depend on the value of $H$. Therefore, Factory will derive no benefit from any reduction in $H$, will have no incentive to make any investment in harm reduction, and will make zero investment.

In contrast, Resort's investment in harm reduction will be set at the socially optimal level. Under the FL rule, Resort will bear the full harm, $H$, only in scenario $F R$, which occurs with a probability of $1 / 2$. In scenarios $F$ and $R$, on the other hand, the value of $H$ would have no effect on the value that Resort would obtain. Resort therefore will invest up to the point where $1 / 2$ of the marginal reduction in $H$ produced by an additional dollar of investment falls to one. As we have seen earlier, this level of investment will be socially optimal.

e. Comparing the Rules. Putting together the conclusions from the preceding subsections, we can now summarize the results concerning the parties' investments in harm reduction under the four different rules: 
TABLE 6. INVESTMENTS IN HARM REDUCTION UNDER ALTERNATIVE RULES

\begin{tabular}{|lcc||}
\hline Rule & $\begin{array}{c}\text { Factory's Investment } \\
\text { in Reducing } \boldsymbol{H}\end{array}$ & $\begin{array}{c}\text { Resort's Investment in } \\
\text { Reducing } \boldsymbol{H}\end{array}$ \\
\hline$R P$ & Suboptimal & Suboptimal \\
\hline$R L$ & Optimal & Zero \\
\hline$F P$ & Zero & Excessive \\
\hline$F L$ & Zero & Optimal \\
\hline
\end{tabular}

As Table 6 indicates, none of the rules will generally ensure that both Factory and Resort invest optimally in harm reduction. This state of affairs arises because, essentially, under none of the rules will both parties obtain benefits that are equal to the expected social benefits produced by their investments.

\section{E. Taking Stock}

Having analyzed the effects of alternative rules on the parties' investments both in enhancing the value of their activities and in harm reduction, we can now turn to an overall comparison of ex ante investments under the four legal rules: 


\section{TABLE 7. OVERALL COMPARISON OF EX ANTE INVESTMENTS UNDER ALTERNATIVE RULES}

\begin{tabular}{|lcccc||}
\hline Rule & $\begin{array}{c}\text { Factory's } \\
\text { Investment } \\
\text { in } \boldsymbol{V}_{\boldsymbol{F}}\end{array}$ & $\begin{array}{c}\text { Resort's In- } \\
\text { vestment in } \\
\boldsymbol{V}_{\boldsymbol{R}}\end{array}$ & $\begin{array}{c}\text { Factory's } \\
\text { Investment } \\
\text { in Reduc- } \\
\text { ing } \boldsymbol{H}\end{array}$ & $\begin{array}{c}\text { Resort's In- } \\
\text { vestment in } \\
\text { Reducing } \boldsymbol{H}\end{array}$ \\
\hline$R P$ & Suboptimal & Excessive & Suboptimal & Suboptimal \\
\hline$R L$ & Optimal & $\begin{array}{c}\text { Most Exces- } \\
\text { sive }\end{array}$ & Optimal & Zero \\
\hline$F P$ & Excessive & Suboptimal & Zero & Excessive \\
\hline$F L$ & $\begin{array}{c}\text { Most Exces- } \\
\text { sive }\end{array}$ & Optimal & Zero & Optimal \\
\hline
\end{tabular}

As Table 7 indicates, none of the rules can ensure that both parties will set both types of investments at the efficient level. Each rule will lead at least two of the four ex ante investments to deviate from the efficient level. Although each one of the rules involves some efficiency costs, the rules are likely to differ considerably in how far they fall short of efficiency. The best rule from the perspective of ex ante investments therefore is the one that would produce the lowest overall inefficiency costs.

\section{IMPLICATIONS FOR THE CHOICE OF RULE}

Having identified and analyzed how legal rules can affect ex ante actions and investments, I now examine the implications of this analysis for the choice of rule. Section A discusses the implications of ex ante effects on the choice between property-right protection and liability-rule protection. Section B considers the choice of party to protect. Section $C$ shows that, once we take ex ante considerations into account, it would be worthwhile to consider an expanded menu of legal rules. Finally, Section D identifies a certain advantage that government fines and taxes have over private law rules in addressing the problems of ex ante incentives. 


\section{The Ex Ante View of the Cathedral}

\section{A. Property-Right Protection vs. Liability-Rule Protection}

One important contribution of the existing literature has been to identify certain important ex post advantages that liability rules have when ex post bargaining is not easy.53 As the discussion will explain, from the ex ante perspective, liability rules are not generally superior. Liability rules sometimes do work better than property rights, but sometimes they do not.

For concreteness, let us suppose that we decide to protect Resort against Factory's pollution, so that we now must decide only whether to protect with a property right or with a liability rule - that is, choose between $R P$ and $R L$. The results displayed in Table 7 suggest that $R L$ does not necessarily work better than $R P$. To understand this more fully, let us first examine how these rules affect Factory's ex ante investments. As Table 7 indicates, a liability rule $(R L)$ would lead Factory to make more efficient investments than a property rule $(R P)$ would.

Specifically, an $R L$ rule would induce Factory to make both valueenhancement and harm-reduction investments at the socially optimal level, whereas an $R P$ rule would induce suboptimal levels of both types of investment. In regard to Resort's ex ante investments, however, liability-rule protection would yield inferior results. Although both an $R L$ and an $R P$ rule would lead Resort to invest excessively in value-enhancement, an $R L$ rule would induce greater over-investment than an $R P$ rule. Furthermore, although both rules would induce suboptimal investment in harm-reduction, Resort would make no investment at all under the $R P$ rule but would make a positive investment under the $R L$ rule.

Thus, the $R P$ rule would produce higher efficiency costs with respect to Factory's ex ante incentives, but the $R L$ rule would produce higher efficiency costs with respect to Resort's ex ante incentives. Superiority from an ex ante perspective will thus depend on the overall balance of these efficiency costs. The balance might favor liability-rule

53. See Ayres \& Talley, supra note 3; Calabresi \& Melamed, supra note 1; Kaplow \& Shavell, supra note 3. Kaplow and Shavell conclude that there is a prima facie case for favoring liability rules over property rights, $i d$. at 721, but they list several factors (including investments by victims in reducing potential harm) that might still make property rights desirable. 
protection in some cases but might favor property-right protection in others. Policymakers wishing to take ex ante efficiency considerations into account should assess the relative magnitude, in the considered context or category of cases, of the factors I identified above. From the ex ante perspective, no general, one-type-fits-all prescription exists. Different categories of cases might therefore call for different forms of protection. Below I offer just a few generalizations about circumstances that would tend to make one form of protection superior to the other.

First, if we find discouraging Factory from inefficient levels of investment much more important than discouraging Resort from inefficient investment, the $R L$ rule will tend to be superior to the $R P$ rule. The intuition underlying this observation runs as follows. The $R L$ rule induces Factory to make optimal ex ante investments both in enhancing the value of its activity and in reducing $H$. On the other hand, Resort's deviations from the optimal level under the $R L$ rule are greater than those under the $R P$ rule. Hence, if Factory's deviations have a sufficiently greater significance than Resort's deviations, the $R L$ rule will be superior.

We can make a similar observation about the case in which minimizing Resort's deviations from its efficient investment levels is viewed as much more important than minimizing Factory's deviations. In this case, the $R P$ rule will tend to be superior to the $R L$ rule.

Finally, the higher the likelihood that scenario $F$ will materialize, the more likely the $R L$ rule will be superior to the $R P$ rule. In this scenario, in which only Factory will ultimately operate, Factory's optimal investment in enhancing its own value becomes more important than Resort's optimal investments in enhancing its value or in reducing harm.

\section{B. Which Party Should Get the Entitlement?}

We now turn to consider the entitlement allocation question: Which party should get the entitlement to the river's water? Should Factory have the right (whichever way it would be protected) to use the water for its activity, or should Resort have the right (again, whichever way it would be protected) to water free of Factory's pollu- 


\section{The Ex Ante View of the Cathedral}

tion? For expositional convenience, I will assume that we will protect the entitlement with a property right. Accordingly, let us consider the choice between FP and RP. Again, the conclusions summarized in Table 7 indicate that neither of the two rules generally dominates the other in terms of ex ante incentives. Each of them has some advantages and some disadvantages when compared with the other.

Consider first how the two rules compare in their effect on the parties' ex ante investments in enhancing the value of their respective activities. Neither rule generally induces optimal investment by Factory in value enhancement. Whereas the $R P$ rule will lead to suboptimal investment, the FP rule will lead to excessive investment. Likewise, neither rule generally induces optimal investment by Resort in value enhancement: in Resort's case, the FP rule leads to suboptimal investment, while the $R P$ rule leads to excessive investment.

Consider next how these two rules compare in terms of their effect on investment in harm reduction. The $R P$ rule always performs better than the FP rule with respect to Factory's investment. The FP rule will lead Factory to make zero investment, whereas the $R P$ rule will lead to a positive (though still suboptimal) investment. With respect to Resort's investment in harm reduction, neither rule systematically dominates the other. The $R P$ rule will lead Resort to make a suboptimal investment, and the $F P$ rule will lead to excessive investment.

From the perspective of ex ante efficiency, whether a property right for Resort or a property right for Factory is better depends on the various factors identified above. Again, the balance of these considerations will tend to vary from one category of cases to another. Below I make just a few observations about circumstances that would likely make one of these rules superior to the other.

When it is especially important to prevent Factory's investment in value enhancement from falling below the efficient level, the ex ante perspective will tend to favor a property right for Factory. The FP rule leads Factory to invest excessively, whereas the $R P$ rule leads to suboptimal investment. On the other hand, when preventing Resort's investment from falling below the efficient level is relatively more important, the ex ante perspective tends to favor a property right for Resort. Whereas the FP rule will lead to suboptimal investment, the $R P$ rule will lead to excessive investment. 
As for investment in harm reduction, the more one wishes Factory to make at least some harm-reducing investments, the more one would tend to favor the $R P$ rule. Whereas the FP rule leads to zero investment by Factory, the $R P$ rule ensures positive (though still suboptimal) investment. On the other hand, when Resort's investments in harm reduction are especially important, the FP rule will tend to be superior. The $R P$ rule will lead Resort to make a suboptimal investment in harm reduction, whereas the FP rule will lead to excessive investment.

\section{Should We Expand the Menu of Rules?}

One important contribution of the Calabresi and Melamed article comes from their classification of four alternative rules to deal with the externality problem. Subsequent literature followed this classification for quite a while, with researchers focusing on these four rules or on a subset of them. In the past several years, however, researchers have put forward additional creative rules, based on the provision of put and call options, to address situations in which courts cannot accurately observe parties' payoffs.54 As long as courts can be assumed to know the parties' payoffs, researchers analyzing liability rules have generally assumed that the level of liability will equal the harm to one party from the other party's decisions and actions. Moreover, when courts are uncertain about the accurate level of harm, researchers have generally assumed that the level of liability will not be set above or below the range of values within which the harm might fall.

Once we recognize that the division of value matters in terms of ex ante incentives, however, we can see that an expanded menu of legal rules might be beneficial. In particular, it might be useful to use liability rules in which liability is set at a level that is known to be higher or lower than harm. Consider our comparison of how the $R P$ and the $R L$ rules divide ex post value. In the event that Factory operates, the $R L$ rule enables Resort to receive an amount equal only to Resort's harm, whereas the $R P$ rule enables Resort to receive part of Factory's surplus also. As a result, the $R L$ rule performs better in terms of Factory's in-

54. See works cited in supra note 11. 


\section{The Ex Ante View of the Cathedral}

vestments, whereas the $R P$ rule performs better in terms of Resort's investments.

These divisions of value produced by the $R L$ and $R P$ rules, however, represent just two possible points along a continuum of possible ex post divisions of value. Other points on this continuum, representing different divisions of value, might produce a better mix of investments. Thus, over- or under-compensatory damages, set above or below the estimated harm, might sometimes lead to an overall more desirable level of ex ante investments.

For example, when considering a choice between $R L$ and $R P$, one might want to consider also a super-compensatory liability rule under which Resort would receive an amount equal, say, to $150 \%$ of its harm, in the event that Factory pollutes. Similarly, when considering a choice between $R L$ and no entitlement to Resort, one might want to consider also a partial liability rule under which Resort would receive damages lower than its actual level of harm, say $50 \%$ of its actual harm, in the event that Factory pollutes.

To be sure, much work still remains before we can identify and analyze the effects of such alternative "intermediate" rules and determine the circumstances under which they would be worthwhile. Once we recognize the influence of ex ante investments, however, we should also recognize the value of exploring such an expansion of legal rules.

\section{Taxes and Fines: Coase vs. Pigou Reconsidered}

The preceding analysis has shown that none of the considered rules can attain the "first-best" outcome - that is, efficient levels of all ex ante investments. Each rule produces some efficiency costs, with at least one of the parties not making the optimal ex ante investment.55 Indeed, the logic of the analysis suggests that no ex post allocation of entitlements, that is, no method for dividing the total ex post value between the parties, could fully eliminate all ex ante inefficiencies. There appears to be no way to divide the ex post value between the parties

55. See the summary of the effects of the four rules on ex ante investments displayed in Table 7, supra. 
in such a way that both parties will at the same time capture fully and exactly the social benefits that their ex ante investments generate. 56

In theory, however, we could achieve a completely efficient outcome through the imposition of government fines. Suppose that, without Resort's help, the government could ex post observe both whether Factory operates and what level of harm Resort suffers from Factory's pollution. Consider also a Government-Fine rule under which, if Factory operates, it must pay the government a fine equal to the social cost of Factory's activity, which in this case equals the harm borne by Resort. The harm to Resort, recall, will equal $H$ when $V_{R}$ exceeds $H$ and Resort therefore continues to operate, but will equal $V_{R}$ when $H$ exceeds $V_{R}$ and Resort therefore decides to shut down.

Under such a Government-Fine rule, each party will internalize all of the effects of its ex ante investments. As a consequence, each party will make the socially optimal ex ante investments both in enhancing the value of its own activity and in reducing potential harm. Essentially, the Government-Fine rule combines the efficiency advantages of both the $R L$ and the $F L$ rule with respect to the investments of both parties.

To start, the Government-Fine rule leaves Factory in the position of the "residual claimant" on its value-enhancing investment. Factory will thus capture fully the marginal social benefits of that investment. Because the Government-Fine rule places Factory in the same position as the $R L$ rule does, in which Factory will always bear neither more nor less than the cost of the harm from its activity, Factory will invest optimally in harm reduction. 57

56. Problems of this type should be familiar to students of law and economics from other contexts. For an excellent discussion, see Cooter, supra note XXX. Although Cooter recognizes that this problem arises in a number of contexts, he does not notice that, in the presence of ex ante investments, it also arises in the context studied in this paper. Indeed, Cooter affirmatively suggests that such a problem does not arise in the context of nuisance disputes when courts use injunctive relief, i.e., property-right protection. See id. at 27-28.

57. See Section IV.B (2) (ii) supra (discussing Factory's level of investment in enhancing its value under the $R L$ rule) and Section IV.D(2)(ii) supra (discussing Factory's level of investment in harm reduction under the $R L$ rule). 


\section{The Ex Ante View of the Cathedral}

Furthermore, whereas the $R L$ rule would not induce optimal investments on the part of Resort, the Government-Fine rule would. With respect to Resort's investments, the Government-Fine rule would produce the same effects as the FL rule. Recall that the FL rule leads Resort to make efficient ex ante investments because it makes Resort the "residual claimant" on its investments both in harm reduction and value enhancement. 58

The efficiency of the Government-Fine rule thus stems from its ability to combine the good effects of both the $R L$ and $F L$ rules. Unlike the $R L$ and FL rules, the Government-Fine rule is not limited to dividing the total ex post value between the two parties. Instead, by introducing the government as a third party, the Government-Fine rule makes Factory and Resort each bear the full harm produced by the externality, which in turn provides both parties with optimal incentives.

Although the law does sometimes use fines or taxes, the Government-Fine rule is certainly not used generally. The explanation for the limited use of fines or taxes might be due to the fact that the assumptions in the above analysis often do not hold true. First, a Government-Fine rule might not be triggered whenever it should. Why would Resort report Factory's pollution when Resort cannot expect any compensation?59 A second difficulty also concerns Resort's willingness to cooperate. Resort would have no incentive to assist the government in assessing the harm produced by Factory's pollution. Indeed, Resort might agree to help Factory, in return for a side payment, by doing whatever possible to lower the estimate of harm.60

58. See Section IV.C.2.iv. supra (discussing Resort's level of investment in enhancing its value under the FL rule) and Section IV.D(2)(iv) supra (discussing Resort's level of investment in harm reduction under the FL rule).

59. The need to rely on private reporting often comes up as one of the relevant considerations in choosing between private and public enforcement of law. See, e.g., Steven Shavell, The Optimal Structure of Law Enforcement, 36 J. L. \& ECON. 255, 267 (1993).

At first glance, the problem might be solved by providing Resort with a financial reward for accurately reporting the magnitude of harm. As Shavell pointed out, however, when Factory's fine exceeds Resort's financial reward, deterrence becomes diluted because Factory will simply bribe Resort not to report with a side payment intermediate between its fine and Resort's financial reward for reporting. See id.; see also Gary S. Becker \& George J. Stigler, Law Enforcement, 
These two problems might well place limits on our ability to take advantage of the potential benefits of government fines.

I wish to conclude this section by relating its analysis to the famous debate between Pigou and Coase. In his influential 1920 work, The Economics of Welfare,61 Pigou advocated the use of government taxes to deal with externalities. Such taxes, Pigou argued, would lead those who create externalities to internalize the costs that their activities impose on others. Economists widely accepted the use of government taxes as the instrument for dealing with externalities for the following forty years.

Coase then challenged the Pigouvian view in his classic 1960 article, The Problem of Social Cost,62 in which Coase took issue with the Pigouvian use of taxes to deal with externalities. To start with, Coase objected to the view that only one party causes an externality. An externality, he pointed out, can be attributable to the joint presence of both parties. In our example, the presence of both Factory and Resort constitute but-for causes of the externality imposed on Resort. Furthermore, and more importantly, Coase argued that taxes might become unnecessary in many situations, such as those in which transaction costs are zero or low. Rather, in such situations private bargaining can attain the efficient outcome without government intervention.

As this Paper has already emphasized, if no impediments exist at any stage in time, bargaining would undoubtedly ensure efficiency and make the use of taxes unnecessary. The analysis of this Paper, however, has focused on situations in which bargaining may be easy ex post but faces great difficulties at some earlier stages in which important ex ante decisions take place. In such situations, we have seen, fines and taxes would have a certain advantage that would make Malfeasance, and Compensation of Enforcers, 3 J. LEGAL STUD. 1, 14 (1974) ("Where victim cooperation aids enforcement, we would expect that, whatever the formal distribution of awards, victims would receive a share.").

61. See A.C. Pigou, The EConomics of Welfare (4th ed. 1932).

62. See Coase, supra note 4 . For a recent account of the debate between Pigou and Coase, see A.W. Brian Simpson, Coase v. Pigou Reexamined, 25 J. LEGALSTUD. 53 (1996); see also R.H. Coase, Law and Economics and A. W. Brian Simpson, 25 J. LEGAL STUD. 103 (1996). 


\section{The Ex Ante View of the Cathedral}

fines and taxes would have a certain advantage that would make them worth considering.

Indeed, the advantage of fines and taxes in such situations can be connected to the fundamental Coasean insight that both sides, Factory and Resort in our example, cause the externality. Consistent with this Coasean view, I focused on the case in which both parties make relevant ex ante investments. When incentives for optimal ex ante investments should be provided to both parties, fines and taxes can be helpful in producing an efficient outcome.

\section{CONCLUSION}

One of the basic questions confronting the law is how to allocate entitlements in the presence of externalities. This Paper has focused on the effects that such allocations have on ex ante investments and actions. Once we take ex ante effects into account, the allocation of entitlements, and the distributive effects it produces, might well be important even when parties can easily bargain ex post. By identifying the various ex ante effects of alternative rules, this Paper has sought to provide a framework for assessing such effects. Such assessment should be an important element in the design of property rights and liability rules. 